\title{
8. Intelligence Uses of Photography and Trophy Photos of Atrocities
}

In October 1942, the Supreme Command issued instructions on the importance and possible use of seized enemy documents. All written official orders, letters, propaganda material, brochures, newspapers, books and especially photographs (be they of individuals, groups or buildings) fell into this category. In the early days of intelligence gathering, the first data arrived in reports from members of the resistance movement who were active in urban locations, as well as from supporters of the Partisan movement, while informants in the units gathered information by analysing the objects and photographs delivered to them. ${ }^{2}$

For certain groups under the German and Ustashe occupation, owning a camera was strictly forbidden. And for those strands of population targeted by the race laws, being caught with a camera could have fatal consequences. From the moment of the quisling Independent State of Croatia's inception, cameras were confiscated from the homes of Jews and Serbs, as were radio receivers and binoculars. ${ }^{3}$ In the ancient city of Zadar on the Adriatic coast, even typewriters were seized from the homes of certain individuals, ${ }^{4}$ while in other parts of the Independent State of Croatia, all Jews were ordered to surrender their bicycles and cars to the authorities. ${ }^{5}$ The trade in photographic chemicals was overseen by the military authorities. They demanded that every seller maintain a record of their customers. The Belgrade photographer Branko Savić recalls this period:

I travelled three times to Ustashe-occupied Zagreb to acquire photo supplies during the period of the Independent State of Croatia, when there weren't any materials available in Belgrade. Sometimes [I travelled] with fake papers, sometimes without them. The police always inspected the 'wrong' suitcase: the one with personal effects inside, rather than the smuggled supplies. On one occasion after the police check I returned to a friend in the waiting room. She said: 'Branko, you're as pale as a ghost. ${ }^{6}$

\footnotetext{
1 Zbornik dokumenata i podataka o narodno-oslobodilačkom ratu jugoslovenskih naroda, vol. II/6: Dokumenta vrhovnog štaba Narodnooslobodilačke vojske Jugoslavije 1942, Belgrade 1957.

2 Zbornik dokumenata i podataka o narodno-oslobodilačkom ratu jugoslovenskih naroda, vol. II/10: Dokumenta vrhovnog štaba Narodnooslobodilačke vojske Jugoslavije 1943, Belgrade 1962.

3 Dušan Lukač, Ustanak u Bosanskoj krajini, Belgrade 1967, pp. 56-57.

4 Zbornik dokumenata i podataka o narodno-oslobodilačkom ratu jugoslovenskih naroda, vol. IX/ 3: Partijsko-politička dokumenta 1943. godine, Belgrade 1967.

5 Stjepan Iveković (ed.), Građa za povijest narodnooslobodilačke borbe u sjeverozapadnoj Hrvatskoj 1941-1945, vol. 1, Zagreb 1981.

6 Snežana Rovčanin, 'Kvadrati filma spojili i most', in: Večernje Novosti, 7 May 2007, URL: https://www.novosti.rs/vesti/naslovna/ reportaze/aktuelno.293.html:197712-Kvadrati-filma-spojili-i-most (accessed 1 June 2021).
} 
Acting in strict secrecy was perhaps most difficult for those photographers in the resistance movement operating in fascist-occupied territory. Their main task was to falsify identification cards, ${ }^{7}$ needed for people to move beyond the city and enter liberated territory. If they were found out, it was imperative that not a single photograph fall into enemy hands. The undercover agents were strictly forbidden from having any photographs of other members of the Partisan movement on them, as we learn from a letter dated 24 June 1942, written by Koloman Barany, a member of the Varaždin District Committee of the Communist Party of Croatia. The letter demonstrates that members were acutely aware that, in the wrong hands, such photographs threatened blowing the cover of the Partisan's underground network. ${ }^{8}$ In Zagreb, the plan for getting people out of occupied territory and into the Partisan units was drawn up by the respective local committee of the Communist Party and was implemented through the activities of five District Committees, with the railway representing a 'district' of its own. Among these committees, a special group was responsible for transferring people and delivering various materials to the liberated territory. In the first year of the war alone, around 25,000 residents of Zagreb left to join Partisan units, using fake identification cards that had been forged by hand. ${ }^{9}$

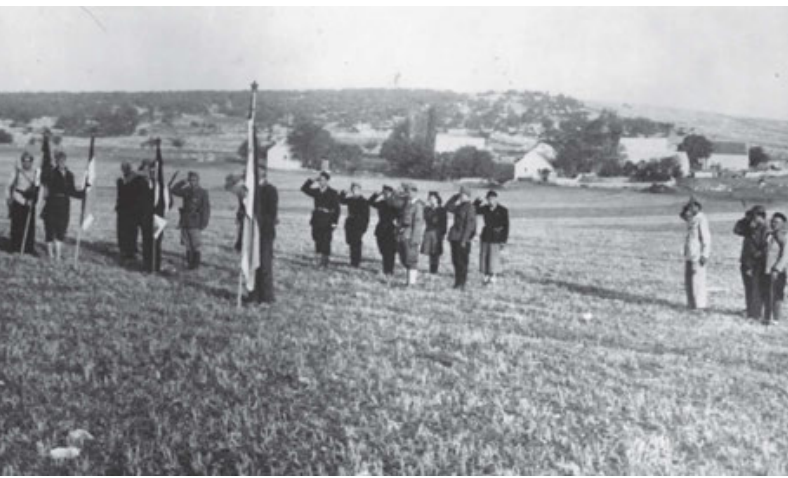

Photograph showing Partisans handing over the flag of the First Dalmatian Brigade, Livanjsko polje, Bosnia and Herzegovina. Photographer unknown. Military Archive Belgrade, K82 F3 16.

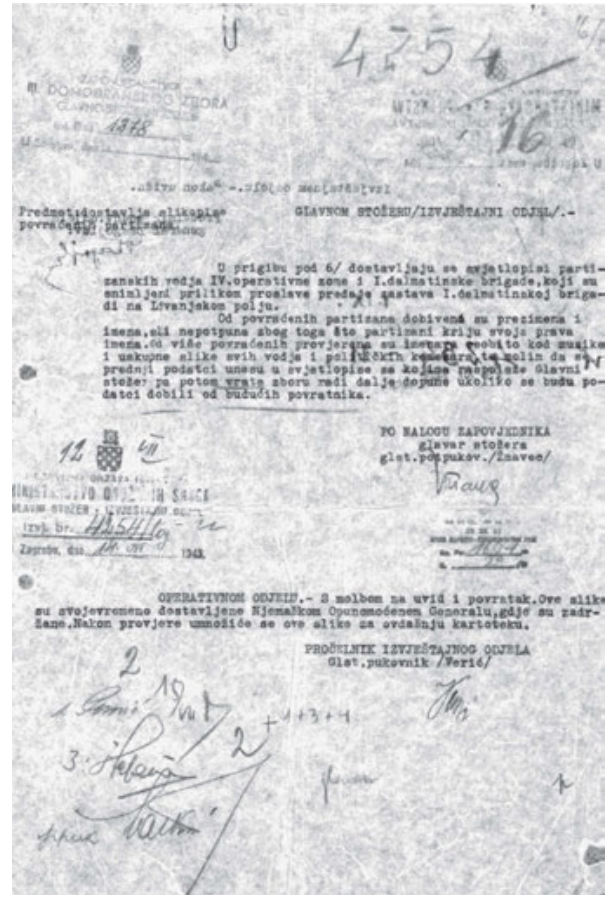

Correspondence accompanying the seized Partisan photograph below, identifying Partisans shown therein. Military Archive Belgrade, K82 F3 16.

7 Norbert Veber, 'Delatnost u okupiranom Zagrebu', in: Veze u NOB: Ratna sećanja 1941-1945, vol. 4., Esad Tihić and Momčilo Kalem (eds.), Belgrade 1981, p. 54.

8 Iveković 1981 (see note 5), vol. 2.

9 Mato Putrić, 'Kako se odlazilo u partizane', in: Večernji list, 26/27 April 1975. 


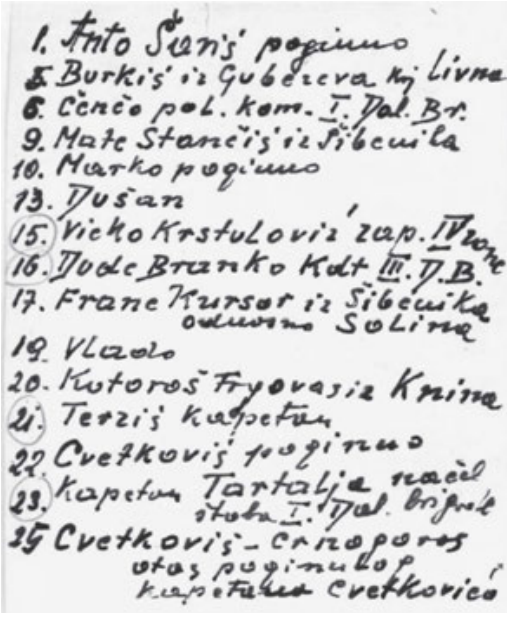

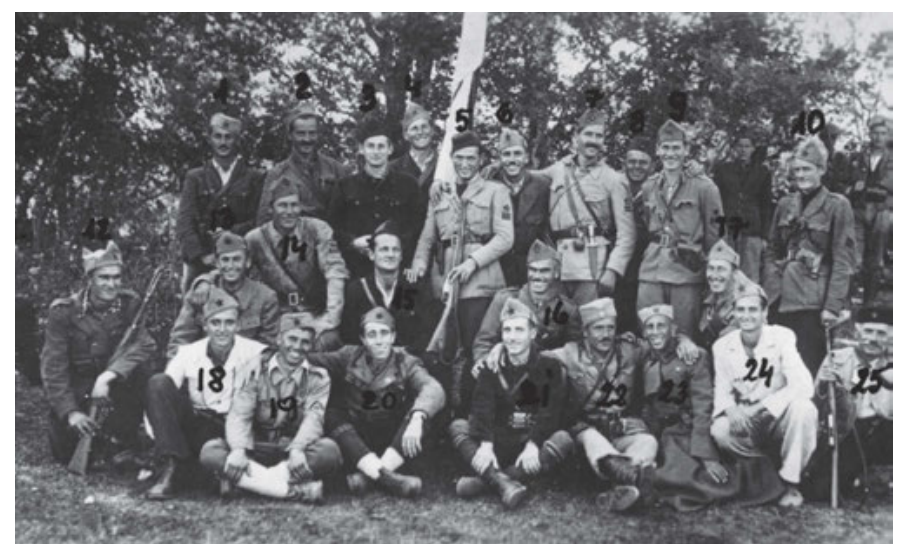

Seized Partisan photograph used to visually identify Partisans. Military Archive Belgrade, K82 F3 16.

List of members of the Partisan movement identified using seized Partisan photographs taken during a flag-handover ceremony of the First Dalmatian Brigade. Military Archive Belgrade, K82 F3 16.

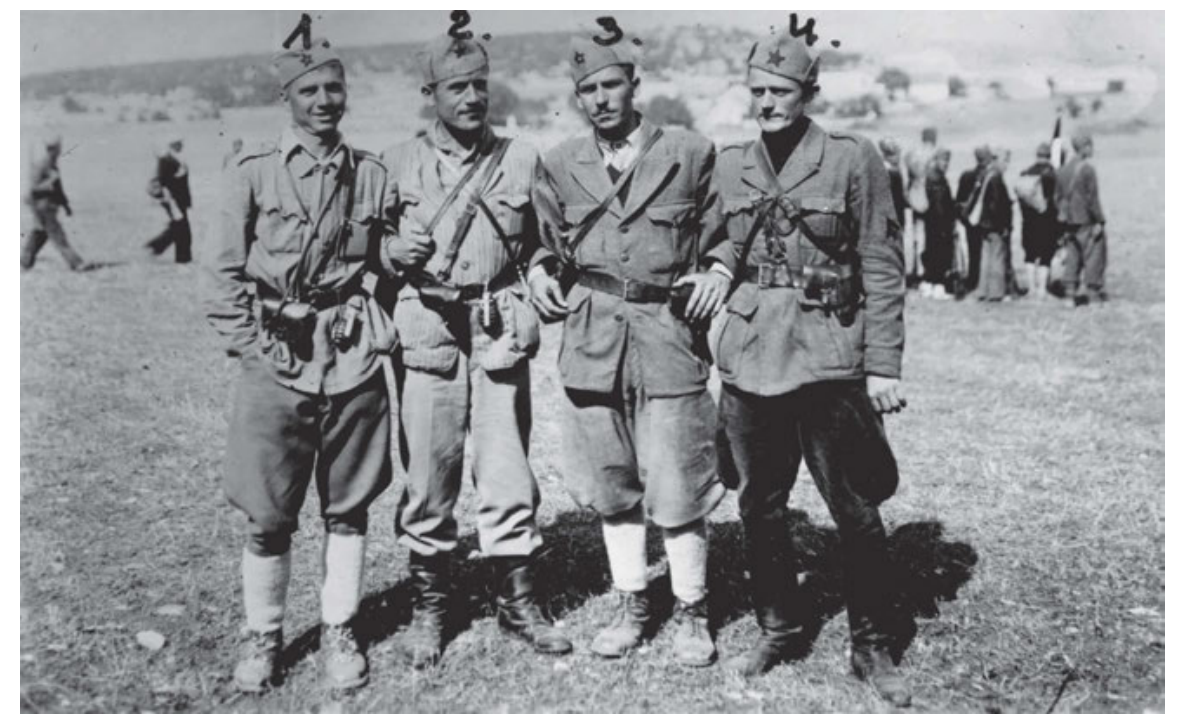

Seized Partisan photograph used to visually identify Partisans. Military Archive Belgrade, K82 F3 16.

1..

2.- Cretkovis Kult. Eriguale - pooinus 3. "Cencio" pol. Komesor I. Talu". brigode 4. - "Marko" Kalt. I. Dalm. brigg a de. puginuo

List of members of the Partisan movement identified using seized Partisan photographs taken during a flag handover-ceremony of the First Dalmatian Brigade. Military Archive Belgrade, K82 F3 16. 
In Zagreb, the first wartime apparatus for producing forged identification documents was located in Dragutin Susović's flat at the address Derenčinova no. 21d. Assisting Susović was a person named Maks Durjava, and it was he who acquired the necessary photographic materials..$^{10}$ Local committee meetings were often held in the flat of photographer Srećko Delhuni, at the address Ilica St. no. $124 .{ }^{11}$ As photographic equipment was all but impossible to acquire unnoticed, the Partisans used existing legitimate channels as a cover instead, through sympathisers employed at photographic supply stores, such as Foto Corsa and the Agfa representative on Ilica St. ${ }^{12}$ When it was no longer possible to get hold of blank identification papers, special substances were used to erase the ink on existing papers, allowing new names to be written in their place. ${ }^{13}$ After producing the photographic prints, all negatives were destroyed. It was the responsibility of undercover agents living in Zagreb to take stealth photographs of notable members of the Ustashe and have the photographs smuggled out to liberated territory. Over time this became a regular practice in other Croatian towns and cities too. It was one way of making an archive to help identify potential double-agents and Ustashe collaborators who had infiltrated the ranks of the Partisans.

Enemy intelligence activities were well-organised and rigorous. On 22 February 1942 in Zagreb, the chiefs of the German military intelligence service, the Abwehr, compiled an ' Album of [Communist] Party and Partisan Leaders', ${ }^{14}$ while the police produced enlarged

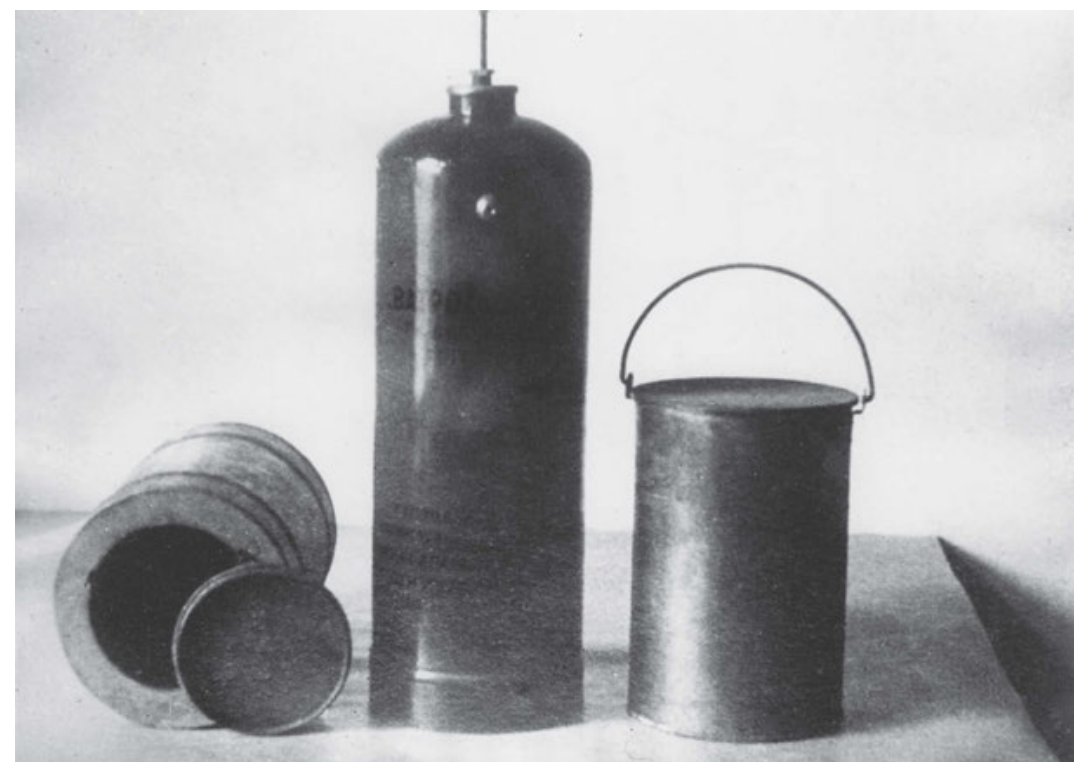

Objects with a false bottom to conceal illegal materials during the occupation, Slovenia. Photographer unknown. Objects now held at National Museum of Contemporary History of Slovenia, Ljubljana, 10902.

10 Stipe Ugarković, 'Partijska tehnika u okupiranom Zagrebu', in: Ustanak naroda Jugoslavije 1941, Belgrade 1964, p. 86.

11 Perica Dozet, 'Moj dolazak u Zagreb', in: Zbornik sjećanja Zagreb 1941-1945, vol. 4, Josip Malić (ed.), Zagreb 1984, p. 20.

12 Dragutin Susović, 'U partijskoj tehnici', in: idem, vol. 3, p. 223.

13 Mila Čobanski, Zvonimir Golubović and Živan Kumanov, Novi Sad u ratu i revoluciji 1941-1945, Novi Sad 1976, p. 419.

14 Nemačka obaveštajna služba (Abwehr, German military secret service), IX. 


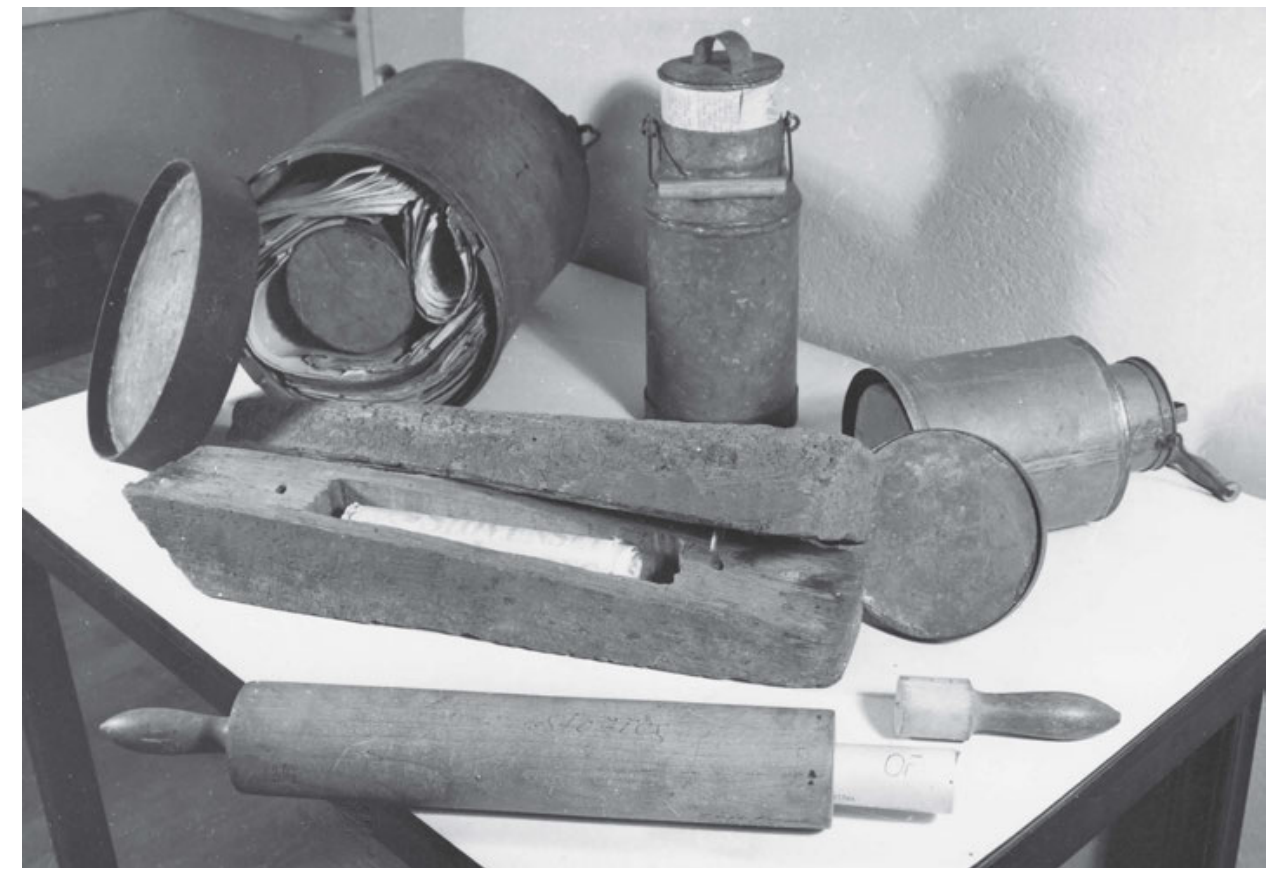

Objects for hiding and passing on secret messages and literature, Slovenia. Photographer unknown. Objects now held at National Museum of Contemporary History of Slovenia, Ljubljana, 10903.

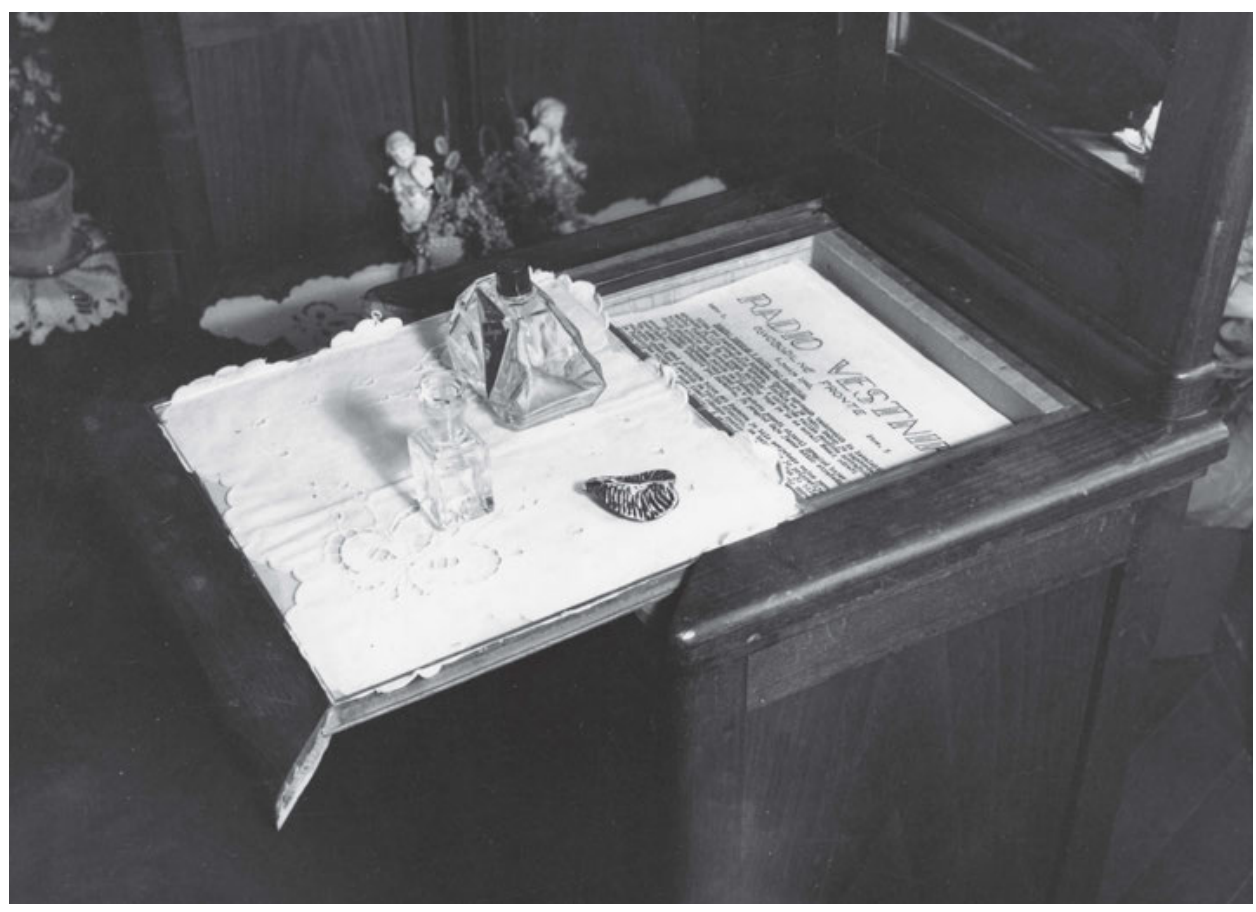

Objects for hiding and passing on secret messages and literature, Slovenia. Photographer unknown. Objects now held at National Museum of Contemporary History of Slovenia, Ljubljana, 10904. 
photos of suspected members of the anti-fascist resistance movement. The photographs and accompanying information gathered on potential resistance suspects were distributed by a network of plain-clothes agents, who had the right to shoot any suspect without warning. ${ }^{15}$

One example of the use of photography in undercover resistance work and counter-espionage is known to us in Rijeka. The photographer Karlo Lau Ritz, resident of Sušak in Rijeka worked for the Gestapo. He was originally from Bela Crkva in Vojvodina (a town in present-day Serbia) and was the owner of the photography shop Foto Desa, which had forged links with the German intelligence service even before the Second World War. He justified his frequent journeys to the German Reich as vocational training during which he attended photography courses. During the war he broadened his intelligence activities by assisting in the arrest of resistance members and even interrogating them in custody ${ }^{16}$ Meanwhile, the resistance movement in Rijeka had an agent named Miculinić working undercover in the police records department. On Mondays and Fridays he would smuggle confidential police records on agents and collaborators out of the office. The photographer Simo Milković would then secretly photograph these papers in a barber shop owned by a certain Živko Jović. He would then develop the prints and send them to the village of Kostrena, where a Partisan courier would pick them up and bring them over the border to liberated territory. ${ }^{17}$

Intelligence and propaganda material also travelled in the other direction - from the liberated territory to the occupied towns and cities. Photographs portraying Partisan successes and war victories were distributed in occupied territory and had an especially disturbing effect on the enemy. The photographs usually chosen were those deemed most impactful ${ }^{18}$ or useful in attracting new recruits or winning over sympathisers. ${ }^{19}$

During the occupation of Zagreb, organisations linked to the League of Communist Youth of Yugoslavia were active in high schools. This organisation included around forty female members and around a hundred female sympathisers. So as not to arouse suspicion, the female members of the League held meetings on Sundays after mass. As part of their regular activities, they organised days out, reading groups and communal trips to the cinema and to academic lectures at the Public Open University (POUZ), an adult-learning centre. After these meetings they also held private debating sessions to discuss what they had heard in the lectures. Notably, in contrast to the other organisations in the League, the girls in this local chapter also formed their own amateur photography group. ${ }^{20}$ Zorka Fak, a pupil at the First Girls' Grammar School, was responsible for distributing photographs of Ustashe crimes.

15 Lepa Perović, 'Ilegalni partijski rad u Zagrebu', in: Malić 1984 (see note 11), vol. 4, p. 11.

16 Radule Butorović, Sušak i Rijeka u NOB, Rijeka 1975, p. 341.

17 Ibid., p. 429.

18 Zbornik dokumenata i podataka o narodno-oslobodilačkom ratu jugoslovenskih naroda, vol. V/4: Borbe u Hrvatskoj 1942. godine, Belgrade 1954.

19 Zbornik dokumenata i podataka o narodno-oslobodilačkom ratu jugoslovenskih naroda, vol. V/30: Borbe u Hrvatskoj 1941-1942. godine, Belgrade 1963.

20 'Djevojke iz treće ženske', in: Revolucionarni omladinski pokret u Zagrebu 1941-1945, vol. 2, Esad Tihić (ed.), Zagreb 1984, p. 150. 
It's difficult to say today how images of the brutal torture of communists, Jews and Serbs in the Ustashe concentration camps got to Zagreb in late 1941. They were horrific testimony to the crimes of the occupiers and their local lackeys [the Croatian Ustashe]. The photographs had to be duplicated and distributed across the city. Comrade Zorka Fak (from the First Girls' Grammar School) turned up at school one day with several such photographs and her fellow pupils set about the task of duplicating them. They turned the pantry in the flat of one pupil living at Deželićeva no. 60 into a small film lab. A few days later, two female members of the League of Communist Youth distributed small packages containing several hundred photographs via their 'connections'. ${ }^{21}$

At that time, the resistance movement also had a stronghold in Dalmatia. Many photographers there were involved in the movement, such as the Split photographer Marcel Njegovan, from Plinarska St. no. 14. On 18 June 1942 the Italian authorities arrested him for smearing black paint over newly erected street signs in Italian. ${ }^{22}$ Information on the first campaigns against the Italian occupiers was published on a fairly regular basis by the fascist paper II popolo di Spalato. In contrast to the German-occupied zone, the Italian military administration chose to distribute photographs of public executions, not realising that such images often only served to antagonise and foment resistance among the local population. Such photographs, taken by or for the occupiers themselves, proved to be excellent source material for Partisan propaganda. Vicko Krstulović obtained several collections of such enemy photographs, and in Donji Lapac, where the editorial offices of the newspaper

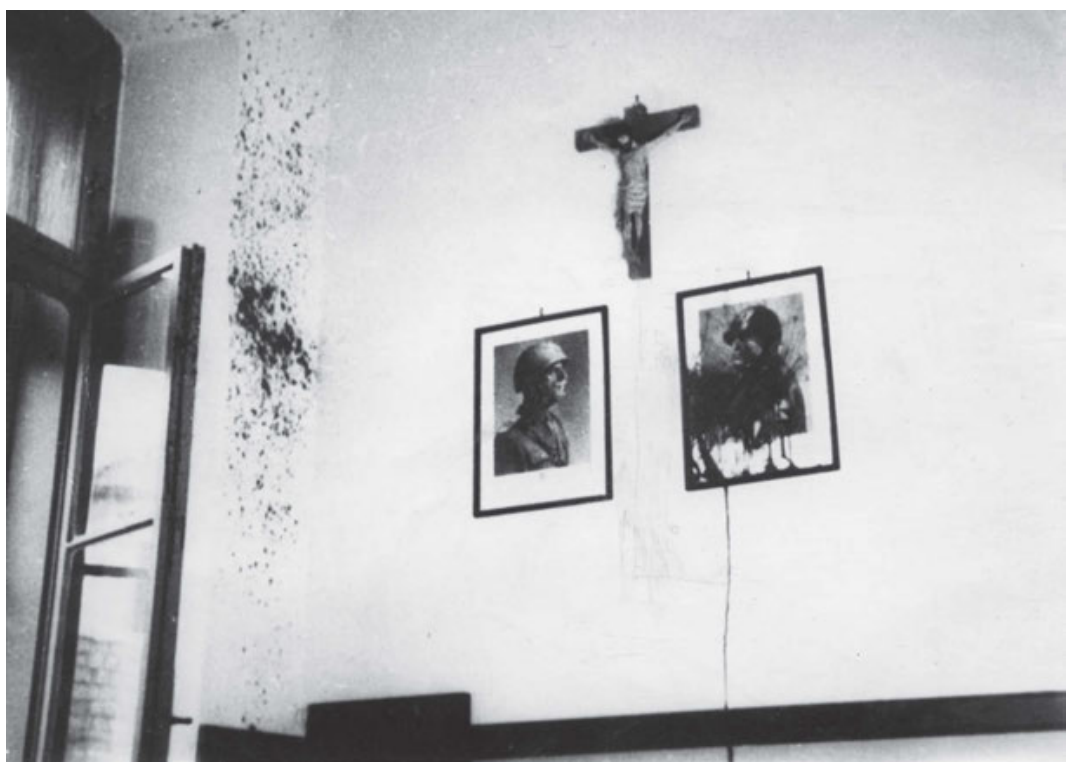

Defaced portrait of 'll Duce', Benito Mussolini, Split, October 1941. Photographer unknown. Croatian History Museum, HPM/MRNH-R-5740.

21 Sofija-Maša Pavičić and Zorka Fak-Horvatić, 'Borbena Prva ženska gimnazija', in: ibid., p. 147.

22 Arhiv VII K 533, reg. no. 38/8-1. 
Vjesnik were situated at the time, he handed over incriminating photographs to Otmar Kreačić-Kultura and Vjera Jurić. These photographs, dated 26 August 1941, documented the execution of members of the Split Detachment. ${ }^{23}$

In Sarajevo, members of the League of Communist Youth of Yugoslavia had been targeting photography exhibitions even before the war. One of the better-known attacks occurred in spring of 1938 when a group of young men led by Vasa Miskina decided to sabotage a photography exhibit organised by the People's Radical Party of Serbia (NRS). The Radical Party's president was Milan Stojadinović, then-ruling prime minister of the Kingdom of Yugoslavia. He enjoyed strong support from Nazi Germany. The members of the League descended on the exhibition and managed to take off with most of the photographs on display, which they then publicly ripped up on the street in front of Sarajevo city hall. ${ }^{24}$

Sarajevo was occupied by the Ustashe at the beginning of the war. On 23 June 1941, the head of the Ustashe headquarters, Ivan Zovko, issued orders to strip Jews and Serbs of their cameras and radios, remove Serbian Cyrillic from signs, and to install Ustashe representatives in Jewish and Serbian-owned businesses. Jewish and Serbian citizens also had their cars, typewriters, bicycles and other valuables taken off them. ${ }^{25}$ Yet at this same moment, Partisan photographs and slogans began to appear in the city, distributed under the cover of night, put up mainly by young men who were members of the League. They included Stevo Nevjestić - a photographer employed in local policing - and Ivica Lisac, who was responsible for the illegal duplication of photographs: ${ }^{26}$

\begin{abstract}
Suddenly, as typically happens in such situations, the League of Communist Youth of Yugoslavia meetings were held, group schedules made, material was distributed and the secretaries were responsible for ensuring their members actively participated in the night-time campaigns, quickly, in synchrony and without losses. The next day, Sarajevo residents found photographs in their letterboxes, on their stairwells, beneath windows, in courtyards, in conspicuous places, thoroughfares and in factories..$^{27}$
\end{abstract}

Gathering intelligence data in Sarajevo was the important job of the Home Guard captain Muhamed Šefkić, and the lieutenant colonel Šefket Hasandedić, who surreptitiously photographed military plans and sketches, before sending them via a go-between to the headquarters of the Tenth Division, delivering exceptionally important intelligence information. ${ }^{28}$ Šefkić and Hasandedić were also responsible for supplying Partisan units with photographic equipment and cameras, and for making fake identification cards. All the material was secretly stored, right under the enemy's nose, in the warehouse of a photo studio

\footnotetext{
23 Vicko Krstulović, Memoari jugoslavenskog revolucionara I, Sarajevo 2012, p. 287.

24 Josif Radić, 'Borba omladine željezničke zanatske škole', in: Sarajevo u revoluciji. U borbi do punog oslobođenja (novembar 1943-april 1945), Nisim Albahari et al. (eds.), Sarajevo 1981, p. 366.

25 Arhiv VII, NDH (Independent State of Croatia) Special Collection, box 171, reg. no. 2/18-1.

26 Mario Mikulić, 'Plakati i Titove slike širom okupiranog Sarajeva', in: Albahari et al. 1981 (see note 24), p. 232.

27 Ibid., p. 233.

28 Milan Đokić, 'O radu posebnog centra V korpusa NOVJ za informacije iz Sarajeva', in: ibid., p. 366.
} 
called Foto Karahasanović, located opposite the Sarajevo Gestapo's headquarters in Hotel Gaza. Besides these two men, a studio named Foto Enis was also used to forge identification papers. In Sarajevo, the first Partisan police photo archive was established in spring 1945. It was the only one of its kind and included 4,000 records with data on suspects of war crimes. $^{29}$

As far as important pre-war photographers are concerned, the Croatian photographer Milan Pavić deserves a special mention. He was a pre-war correspondent for the biggest Yugoslav daily, Politika. At the start of the war, Pavić lived and worked in the Croatian town of Daruvar Active in the Partisan movement, he was responsible for smuggling people over the border into liberated territory and for making fake ID. However, his group's activities were very quickly uncovered by the Ustashe. After his arrest and a prison sentence, Pavić was released. He soon began working for the Ustashe Photography Service of the Independent State of Croatia in Zagreb as an infiltrator. Risking his own life, he continued to work undercover for the anti-fascist movement throughout the war, primarily on intelligence jobs. He also managed to provide the movement with photography equipment, chiefly photochemicals and paper, and later medicines, too. ${ }^{30}$ Midway through 1944 he started working as a Zagreb correspondent for the Partisan press. He secretly gathered information from the very highest levels of the Ustashe administration, at first once a week, then twice, then even three times a week, recording the material in secret code. He wrote his reports in his flat at Buconjićeva St. no. 6/1, as if reporting from liberated territory and not the heart of occupied Zagreb. The reports were then surreptitiously handed over to his go-between, an engineer named Machaček who lived at Istarska St. no. 17. He, in turn, handed them over to a radio-telegraphist named Ljerka Dulčić who lived in another neighbourhood of Zagreb. ${ }^{31}$ In April 1945, Pavić worked with Machaček and Bishop Gabrijel Bukatko in secretly photographing the Jasenovac concentration camp for Allied reconnaissance, giving the Allies knowledge of the camp's precise location and thus preventing Allied bombs from falling on camp prisoners. Pavić was responsible for the transcript of the Ustashe memorandum of surrender sent by Ustashe leader Ante Pavelić to the Western Allies seeking protection..$^{32}$

There was one point at which Pavić should have left Zagreb and joined the ZAVNOH along with a larger group of anti-fascists, but the Ustashe authorities uncovered his plan and stopped him from leaving Zagreb for liberated territory. Pavić remained in Zagreb and at the start of 1945, the Ustashe authorities gave him the task of following and filming the journey of the Ustashe Guard to the Jasenovac concentration camp, while the Partisans simultaneously tasked him with secretly taking pictures of the camp. ${ }^{33}$

29 Zvonko Grbac, 'O vojnoobavještajnom radu za NOP u neprijateljskim vojnim i drugim institucijama', in: ibid.,

p. 619.

30 Milan Pavić, 'Kamera je zabilježila posljednje događaje u Zagrebu', in: Malić 1984 (see note 11), p. 394.

31 Ibid., p. 395.

32 Ibid., pp. 395-396.

33 Ibid., p. 394. 


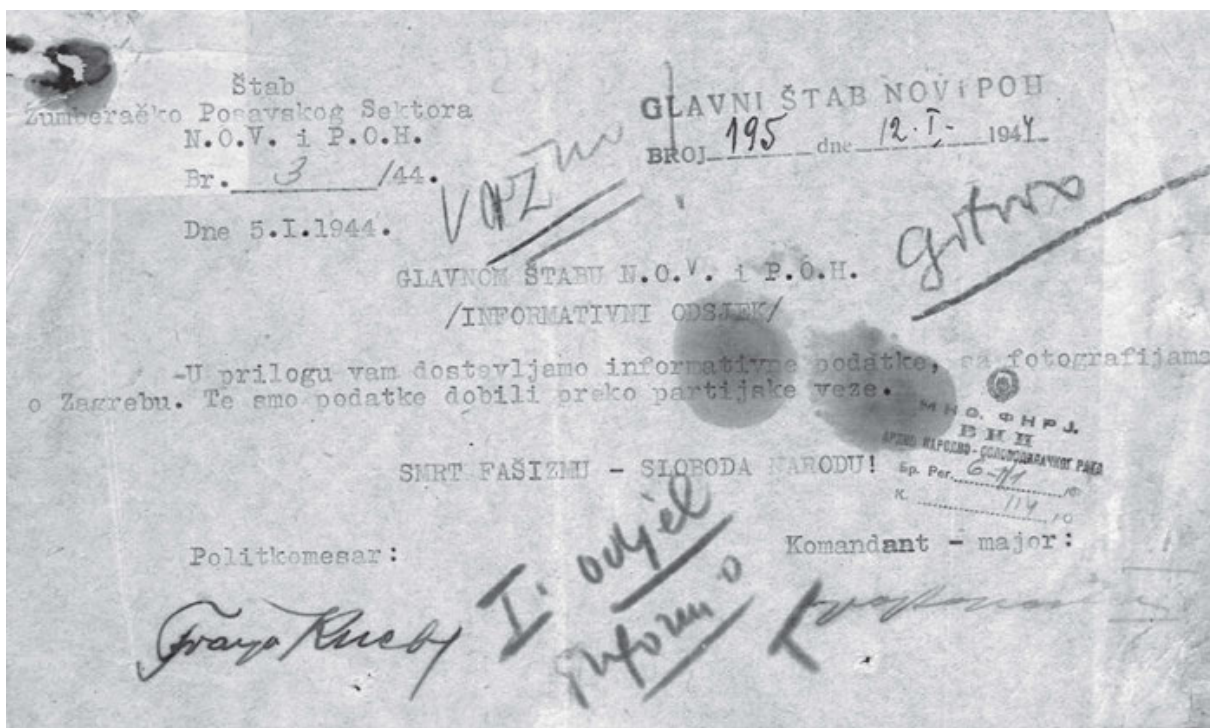

Intelligence data with photographs of Zagreb. Military Archive Belgrade, K114 F1 6.

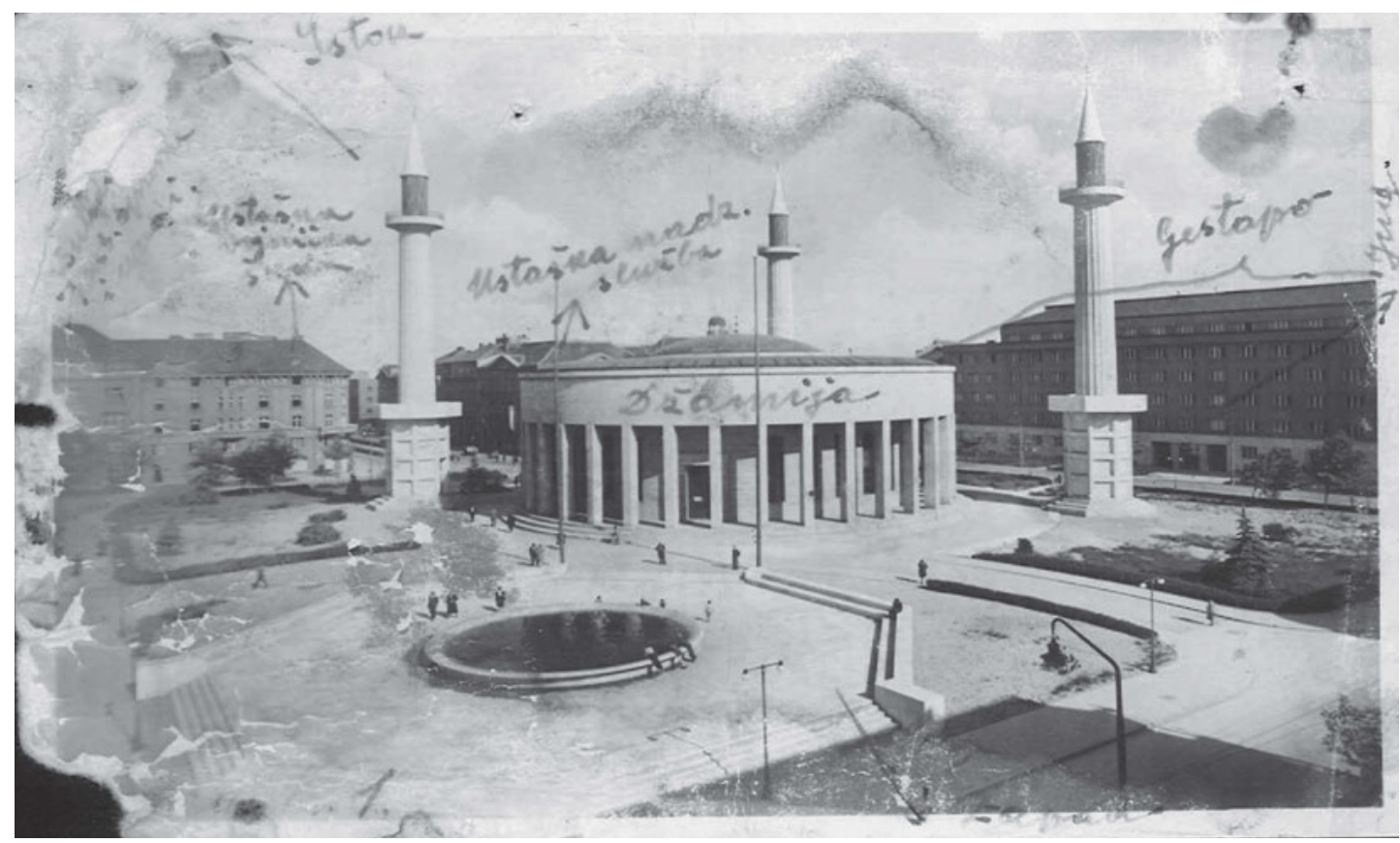

Intelligence data with photographs of Zagreb. Military Archive Belgrade, K114 F1 6. 


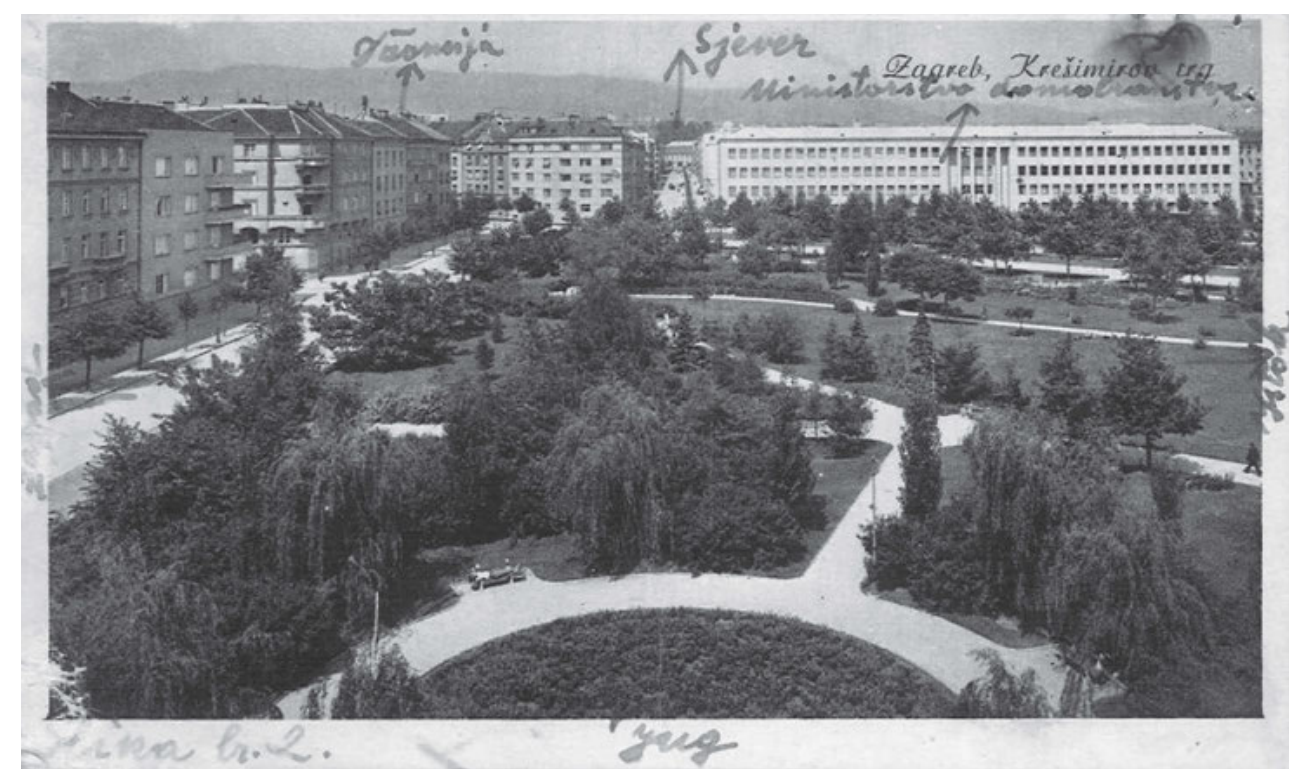

Intelligence data with photographs of Zagreb. Military Archive Belgrade, K114 F1 6.

Commandant Luburić banned us from filming, but he said that if we saw something positive that could be used for propaganda, then we should ask him or his deputy, Colonel Džala, about each shot, and if we didn't ask, then he'd have us locked up in the concentration camp for the rest of our lives. From the control tower at the entrance to the camp (height $18 \mathrm{~m}$ ), with Džala's permission I took three panoramic shots (negatives $6 \times 6 \mathrm{~cm}$ ) of the entire camp. That day, the local prefect Servaci Maks Luburić was awarding medals marking the fourth anniversary of the Ustashe Inspectorate, which he gave to his next-in-command and fellow henchmen, the colonels Pavlović, Džala and others. I used this opportunity to take a portrait photograph of Luburić (whose picture had not appeared in the press up to that point), and each of his abettors in the slaughter, one by one. Upon returning to Zagreb, I printed the photographs in $13 \times 18 \mathrm{~cm}$ format, together with photos of the entire concentration camp (a montage of three shots). I handed everything over to my case officer (Duško Doder), and he smuggled them to the liberated territory. All shots (negatives) were put in the propaganda photo archive, and the shots of the concentration camp from the tower were put in the top-secret archive. ${ }^{34}$ 
As with Branko Savić's camerawork, Pavić's photographs of Jasenovac appear not to have survived. The part of the Ustashe photo archive that Pavić managed to preserve ended up at the Photo-Documentation Agency (Agencija za fotodokumentaciju), but it would seem these particular photographs of his were lost. Near the end of the war, Pavić was tasked with setting up a Partisan photography unit in Zagreb capable of producing photographs for press and propaganda purposes:

Eight days before the liberation [of Zagreb] I received an order from a high-ranking agent to establish undercover contact with the photographer Tošo Dabac who had a studio and film lab at Ilica St. no. 71/1. I was supposed to ask him whether he would be willing to make his lab available for propaganda purposes after the liberation, in the event of the propaganda building being blown up, which was a distinct possibility then. I approached Dabac, as a fellow photographer and an acquaintance, on what is now the Square of Brotherhood and Unity [since renamed Cvjetni Trg] and set out the demands of the People's Liberation Movement. He looked at me first in disbelief and amazement, and then agreed without reservation to put his lab at our service..$^{35}$

Throughout the war it was strictly forbidden for anyone to take photographs of concentration camps, both from inside and outside without a permit; the offence was punishable by death. ${ }^{36}$ Despite this, certain individuals deliberately risked their lives by breaking this law, as was the case with the railway engineer Mato Đukić, who took pictures of the Jasenovac concentration camp from a distance. Meanwhile, 'insider' photographs are known to have existed: Several camp prisoners stated on record that Dominik 'Hinko' Piccili - the Ustashe lieutenant colonel and infamous commander of the section Ciglana III (Brickyard III) who had a primitive crematorium built to incinerate prisoners, some while still alive ${ }^{37}$ - used to walk around the camp with his Leica taking pictures of prisoners. ${ }^{38}$ In Belgrade, the deputy director of the Banjica concentration camp, Peter Kriger, renowned for his especially inhuman and cruel behaviour, was known to ride around the camp on a bicycle, similarly photographing camp prisoners whenever anything seemed suspicious to him. ${ }^{39}$

The members of the underground resistance movement often themselves did not even know who other members were. In 1943 Pavić could not have assumed that Tošo Dabac (the photographer mentioned earlier with a film lab at Ilica St. no. 71/1) was increasingly distancing himself from propaganda jobs he had done for the Ustashe regime and had in fact switched sides, delivering photography equipment and material to the Partisans. Dabac donated his Contax // camera, photometer and photographic supplies worth 20,000 kunas at that time - which landed him in prison in September $1944 .{ }^{40}$ In the last month of war, on 5 April 1945, Partisan agents in Zagreb managed to secretly photograph and smuggle out to Tito's Ministry of People's Defence (as it was already known by then) the

\footnotetext{
35 Ibid., p. 396.

36 Nataša Mataušić, Koncentracioni logor Jasenovac, Zagreb 2008, p. 30.

37 Unknown author, 'Dominik Hinko Piccili (Pićili) ustaški pukovnik', in: Jasenovac Memorial Site, URL: http://www.jusp-jasenovac.

hr/Default.aspx?sid=6248 (accessed 1 June 2021).

38 Mataušić 2008 (see note 36), pp. 28-29.

39 Sima Begović, Logor Banjica 1941-1944, vol. 2, Belgrade 1989, p. 102.

40 Iva Prosoli, Monografska obrada umjetničkog opusa Toše Dabca, doctoral thesis, Filozofski fakultet Sveučilišta u Zagrebu,

Zagreb 2018, pp. 137-138.
} 


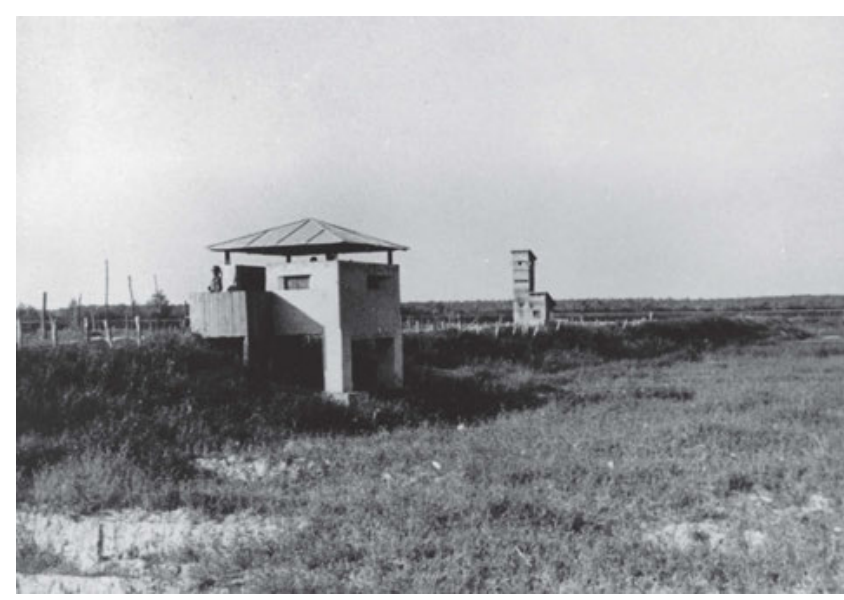

The Jasenovac concentration camp tower, equipped with floodlights and machine guns. Photographer unknown. History Museum of Bosnia and Herzegovina, FNOB 2029.

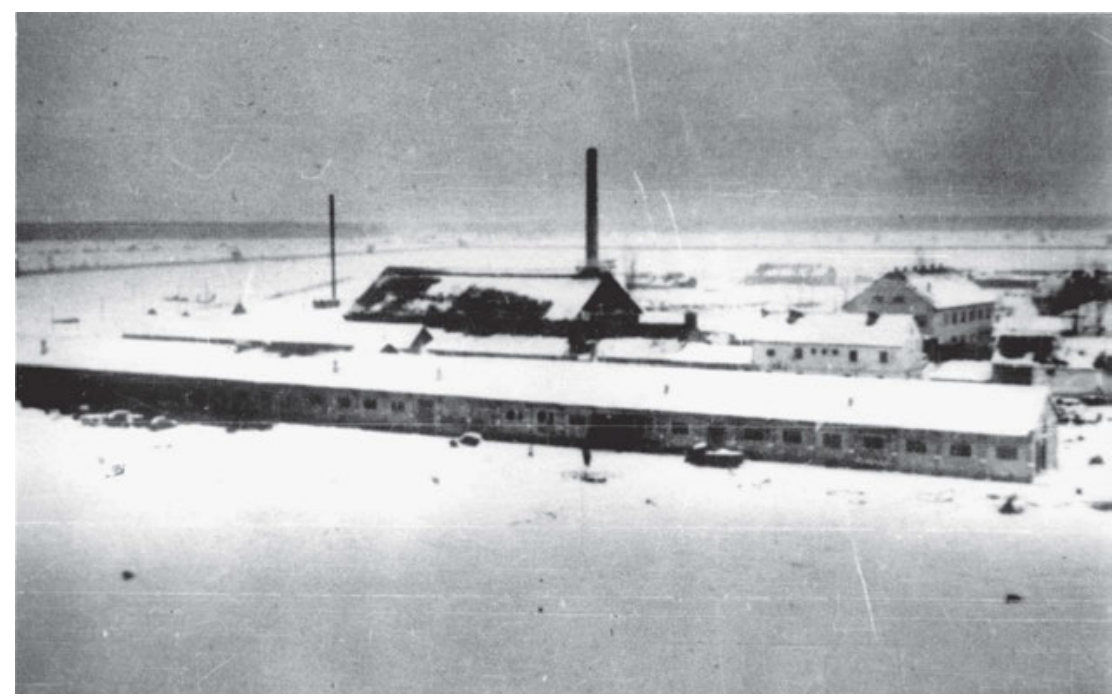

Jasenovac concentration camp in winter. Photographer unknown. Yad Vashem, 42913.

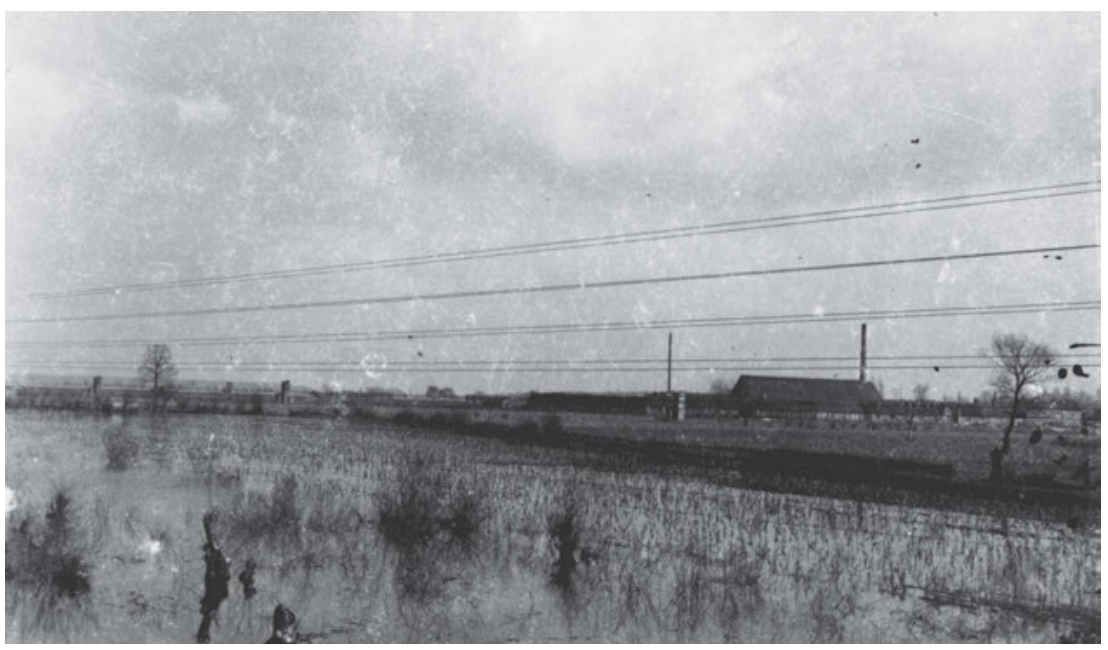

Jasenovac. Photograph taken by railway engineer Mato Đukić, 1942.

Jasenovac Memorial Site, accession no. unknown. 
Ustashe plans for mounting a last defence of the city. ${ }^{41}$ Pavić's photographs of the liberation of Zagreb include some of the most important photographs recording the liberation on 8 May 1945 and the period immediately before it. According to eye-witness accounts, during those eight days, Chetniks, broken German formations, civilians, Home Guard and Ustashe passed through Zagreb day and night, while the citizens were gripped by an indescribable fear. Some photographs of Zagreb's liberation were also shot by the underground agent Stjepan Puba Cerjan, who narrowly avoided arrest when trying to say goodbye to his parents just before leaving to join the Partisans. ${ }^{42}$ Besides Cerjan, the only other person to attain a permit to take pictures of the Partisan units entering Zagreb was Tošo Dabac, who notably approached the task with a critical eye and sense of detachment.

In the Slovenian capital of Ljubljana, the Anti-Imperialist Front was founded in late April 1941 and soon changed its name to the Liberation Front of the Slovenian People. The first Liberation Front campaigns were recorded by the photographers Miran Pavlin, Dr Jakob Prešern, ${ }^{43}$ Viktor Kramar and Jože Stajer, and their film rolls were sent to Partisan units on liberated territory. Similar networks involving photographers were set up in other Slovenian cities. ${ }^{44}$ The Liberation Front operated illegally, organising the printing of propaganda pamphlets, and their photographers also carried out the technical work required to make passport photographs for fake identification. One especially interesting detail about the campaign in Slovenia is that many photography studios took the brave decision to secretly make copies of photographic material that the Italian and German occupying authorities brought to them. Such 'intelligence gathering' began very early on, in 1941. Following an order by the poet Karel Destovnik-Kajuh, Stane Viršek organised a group of fifteen people to carry out this work. ${ }^{45}$ Edi Šelhaus in Škofja Loka documented occupier war crimes in the same way, ${ }^{46}$ and in Celje, Josip Pelikan, working as an official photographer for the Germans, managed to keep photographs of the execution of civilians incarcerated in Stari Pisker. The question of who shot these photographs has never been entirely clarified, but Pelikan was the person responsible for the photo archive that documented the terrible conditions that prevailed during the German occupation of Celje, and his archive has been preserved to this day.

The Stari Pisker prison wing is presently part of Celje Prison, and its courtyard has been turned into a memorial space open to the public. During the war, around 10,000 people are estimated to have passed through this prison, and executions were carried out on at least six occasions in its courtyard. The greatest known atrocity occurred on 22 July 1942, when units from the German SS decided to murder all prisoners in detention at that moment in

41 Zbornik dokumenata i podataka o narodno-oslobodilačkom ratu jugoslovenskih naroda, vol. II/15, Belgrade 1982.

42 Stjepan Cerjan, 'Ustaj, evo ustaša!', in: Tihić 1984 (see note 20), p. 95.

43 Franc Fabec, 'Photography during the Slovene National Liberation Struggle', in: Resistance, Suffering, Hope: The Slovene Parti-

san Movement 1941-1945, Jože Pirjevec and Bože Repe, Ljubljana/Trieste 2008, p. 95.

44 For a detailed list of names, see the book by Franc Fabec and Dejan Vončina, Slovenska odporniška fotografija 1941-1945, Ljubljana 2005.

45 Ibid., p. 23.

46 Fabec 2008 (see note 43), p. 95 


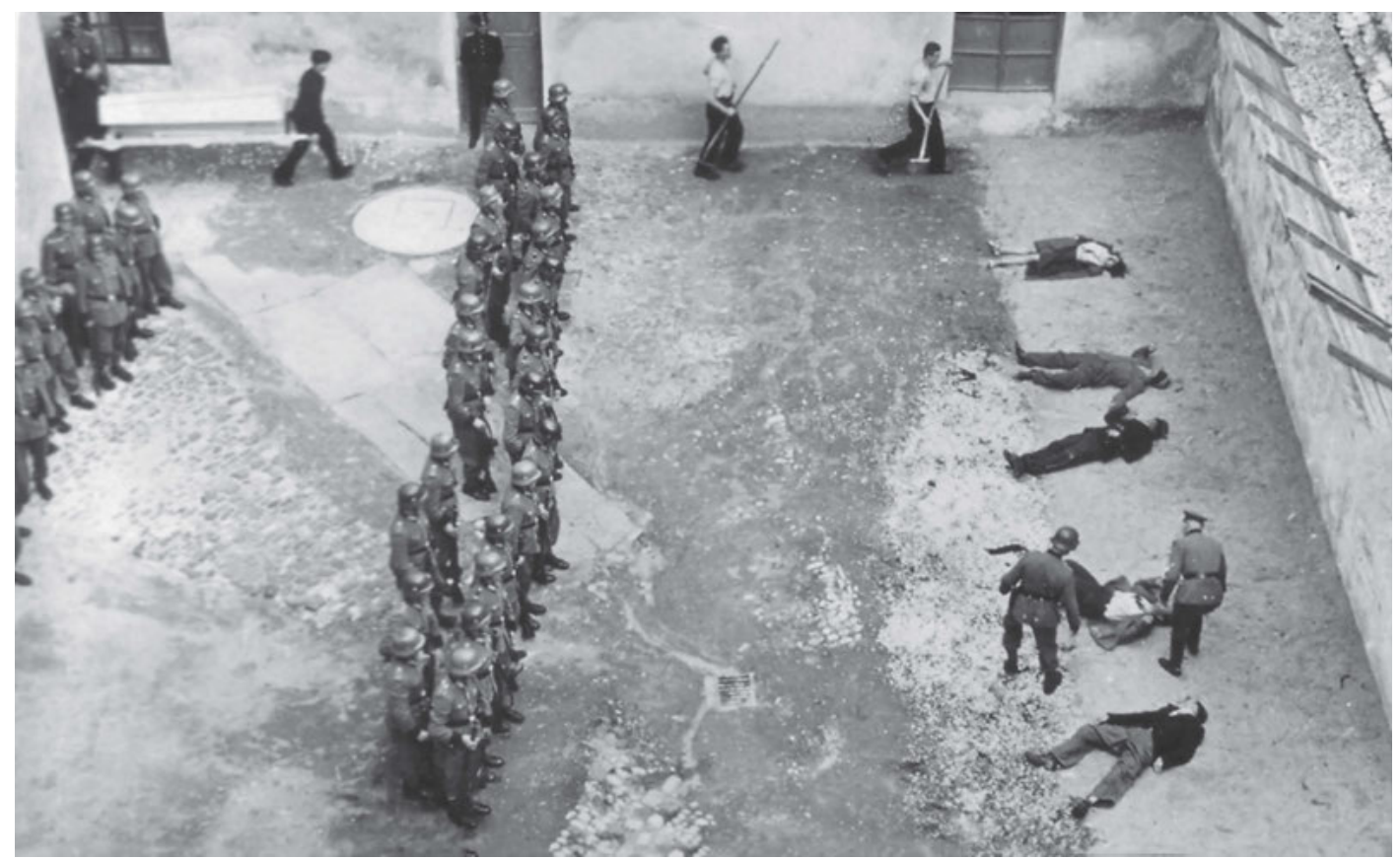

After an execution by firing squad at Celje, 22 July 1942. Photographer unknown. Museum of Recent History, Celje, VF 96.

an act of retaliation. To this day, the Museum of Recent History, Celje has preserved their farewell letters, which are distressing testimonies of Nazi brutality.

In 1942, Pelikan also took photographs of the so-called 'shaming' of the Partisans. These practices included displaying the dead bodies of killed Partisans, while their captured comrades were forced to stand above them, wearing humiliating placards as civilians and German soldiers walked by to observe the spectacle. One of the photographs shows Tončka Čeč (a Partisan with the codename Roza), a pre-war communist and member of the Liberation Front who died in Auschwitz on 3 November 1943 as a result of a typhus infection. One photograph depicting her is particularly haunting:

Dead bodies are strewn across the pavement, while civilians and German soldiers pass them by. Only the gentlemen in suits are relaxed. They are chatting. Their bodies show no sign of tension. Pelikan is neat, focused and pays attention to the composition. He chooses a wide shot that captures the dead, the living and those being tortured. He includes everything in the frame. $\mathrm{He}$ can jump over the rope and enter the protected area. He moves the lens to the right and on the right-hand side he foregrounds a woman whose face is difficult to distinguish. Her head is gently raised and turned to her left. And she stands proud. You feel her strength, despite the fact she is captured and her hands are tied. ${ }^{47}$ 
In Serbia, meanwhile, the illegal printing press of the Central Committee of the Communist Party of Yugoslavia operated throughout the entire war, publishing the Glas Jedinstvenog narodno-oslobodilačkog fronta Srbije (Voice of the United People's Liberation Front of Serbia).

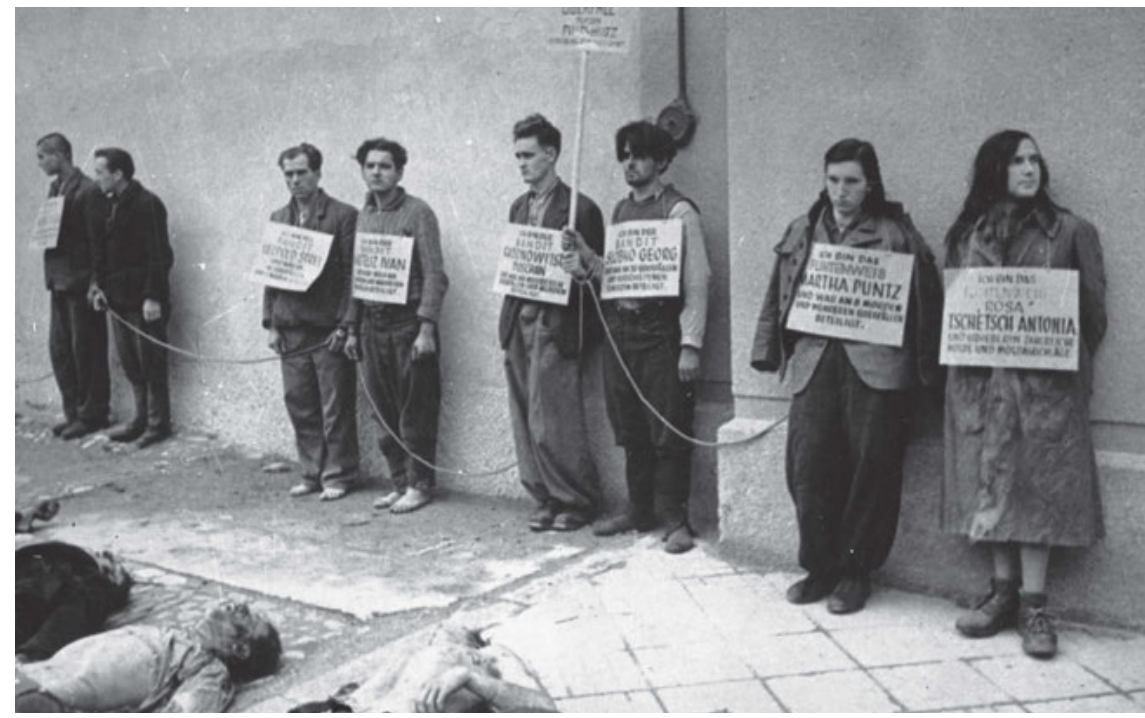

Tončka Čeč (right), Celje, 1942. Photographer unknown. Museum of Recent History, Celje.

Many members and supporters of the anti-fascist movement collaborated on the paper writers, artists and journalists. Despite many arrests, the underground printing press was active from the beginning of the war up until 28 July 1944, when members of the special police, the Gestapo and the quisling gendarmerie raided its secret location, then at a house at Daničareva no. 24. The typesetters Slobodan Jović and Branko Đonović first set about destroying secret documents, before putting up armed resistance. Finding themselves trapped, the two friends turned their guns on themselves, each firing a lethal shot at the other after a count of three, so as to evade police capture. The married couple Ratka and Milutin Blagojević also died in the raid. ${ }^{48}$

German units in occupied Yugoslavia carried out mass executions that were documented by the German propaganda unit Propaganda-Abteilung Südost which was active in the Yugoslav region from October 1941 onwards. Stationed in Belgrade, the unit's task was to produce propaganda material intended for the local population. ${ }^{49}$ In the German troops, there was a clear hierarchy of photographic production from the very beginning: from acquiring photographic material, taking photographs, developing film and making positives, to the distribu-

48 Milan Radanović, 'llegalna štamparija Pokrajinskog komiteta KPJ za Srbiju Daničareva 24', in: Mesta stradanja i antifašističke borbe u Beogradu 1941-1944. Priručnik za čitanje grada. Milovan Pisarri and Rena Rädle (eds.), Belgrade 2016 (Rosa Luxemburg Stiftung Southeast Europe), pp. 109-111.

49 Daniel Uziel, The Propaganda Warriors: The Wehrmacht and the Consolidation of the German Home Front, Bern 2008, p. 287. 
tion of photographs. An order by the counter-intelligence department of the Oberkommando der Wehrmacht (OKW), dated 28 November 1941, labelled 'confidential', states that it is explicitly forbidden to photograph the faces of those sentenced to death by firing squad:

1. Taking photographs of shootings after sentencing by military court is forbidden in general. If, in certain exceptional cases, it is necessary to make photographic images for purely military goals, approval can only be granted by an officer of a rank no lower than division commander. Used film that has not been developed should be submitted to superiors as 'Confidential OKW/W. $\operatorname{Pr}$ [Wehrmachtpropaganda]', with the concurrent request that certain images be produced.

2. In striving to carry out this order, military organs ordered to carry out executions of death by firing squad are required to take all necessary precautionary measures to ensure that there are no viewers. Any images and negatives already in existence from previous executions should be removed from circulation, and if possible, be submitted to the Oberkommando des Heeres.

Contrary to this order, pictures of war crimes were often to be found on German soldiers trophy photographs that they collected as proof of the struggle against the 'bandits' - their name for the Partisan units, as they refused to recognise them as a legitimate military organisation. Making photo albums, of themselves but also of their victims, was an especially popular pastime among German soldiers. Such albums depicted deportations, executions, public hangings and the debasement of the occupied peoples, along with routine acts of violence. ${ }^{50}$ One such example is a postcard showing three hanged civilians with the caption 'Trees in Blossom, Serbia 1941'.51 While writing to their families in Germany, some German soldiers even sent trophy photographs of war crimes, even though this directly violated paragraph 25 of the German Military Code, which penalised such behaviour as failing to respect military secrets, and paragraphs 90d and 90e of the Penal Code relating to acts of treason. ${ }^{52}$

The National Museum of Contemporary History of Slovenia in Ljubljana is home to the photo albums of several SS officers. These are painstakingly made scrapbooks of brutality that include composite photographs of crimes against Partisan soldiers, arranged in a linear montage. Such photographs sometimes became special trophies, as was the case with pictures of the German SS battalion in the Slovenian village of Masor, when two civilians and three Partisans from the Vojko Brigade were killed. This was also the case with photographs dated 20 March 1945 and taken in the village of Sedej next to a settlement called Idrijske Krnice.

In Croatia, data on trophy photographs can be found in the report of the Staff of the Third Operative Zone to the General Staff of the People's Liberation Army and the Partisan Detachment of Croatia. The report, dated 23 May 1943, covers the work of the intelligence

\footnotetext{
50 Sandra Vitaljić, Rat slikama. Suvremena ratna fotografija, Zagreb/Mostar 2013, p. 93.

51 Trials of War Criminals Before the Nuremberg Military Tribunals Under Council Law, no. 10, vol. XI, United States Government Printing Office Washington 1950, p. 1147.

52 Valter Manošek, Holokaust u Srbiji. Vojna okupaciona politika i uništavanje Jevreja 1941-1942, Belgrade 2007, p. 90.
} 
service. It states that in an attack on Slavonski zdrug at Voćin, the captured officers had photographs of war crimes on their person..$^{53}$ Similar photographs were found on German officers, especially at Kozara. ${ }^{54}$

Civilians were hanged, often as an act of retribution, all over Yugoslavia. Yet one of the most brutal atrocities committed were the mass killings in the city cemetery in Pančevo on 22 April 1941, photographed by Gerhard Gronefeld in a company of the Wehrmachtpropaganda service. Gottfried Kessel, a second member in this company, recorded the hangings and murders on camera using colour film. Years later, Gronefeld said that these photographs had haunted him for the rest of his life. ${ }^{55}$ The victims were degraded even in death their bodies put on show to German soldiers and crowds of civilians. Hats were placed on their heads as a macabre insinuation that only dead and hanged like this were they afforded the status of proper gentlemen, being peasants otherwise. This is reminiscent of the communists whose bodies were put on public display, degraded and photographed after the collapse of Paris Commune. It also calls to mind the Slovenian communists who were
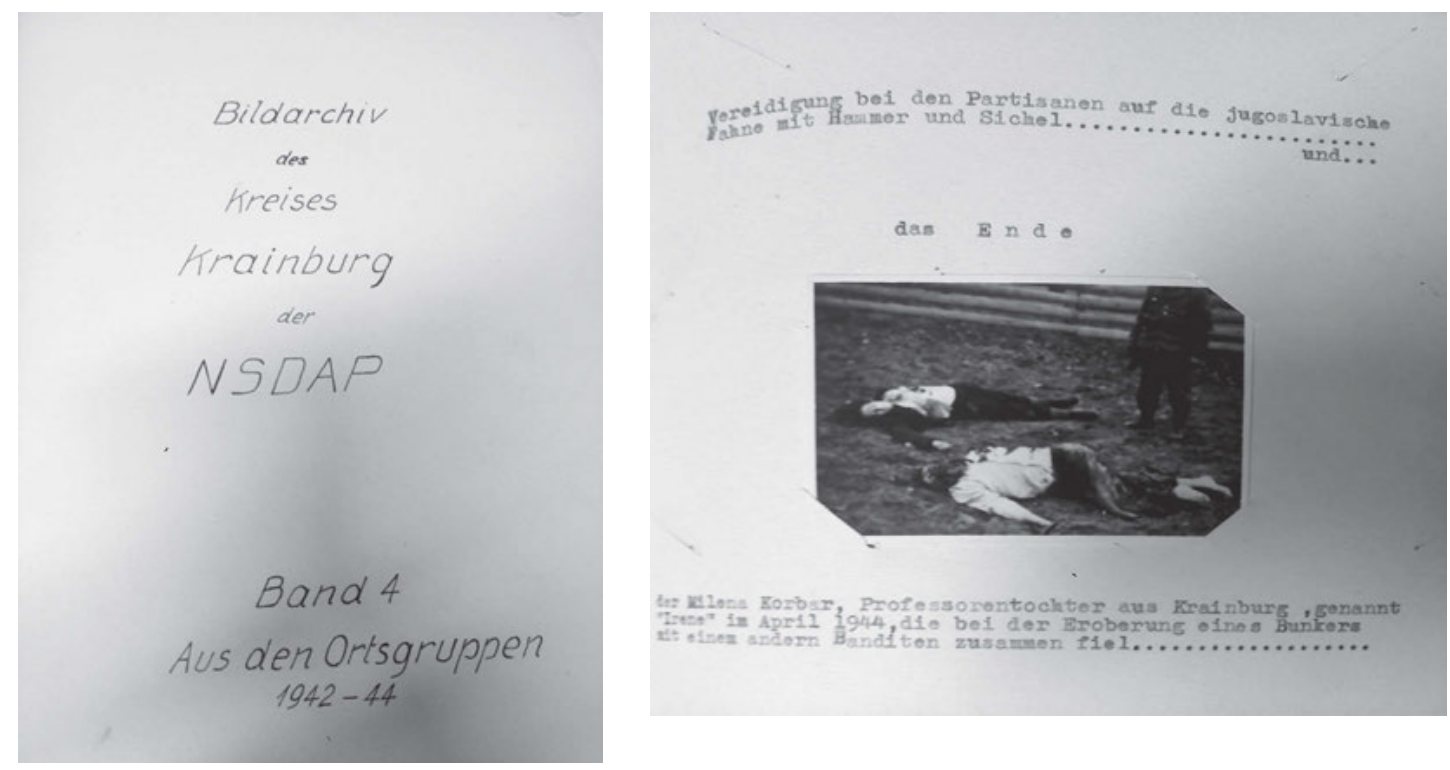

Photo album: 'Picture Archive of the District of Krainburg [Kranj] of the National Socialist German Workers' Party. Volume 4. From the local groups'. National Museum of Contemporary History of Slovenia.

53 Građa za historiju NOP u Slavoniji, knjiga, vol. 5 (1.4.-31.5.1943.), Slavonski Brod 1966.

54 Ljubomir Borojević, Dušan Samardžija and Rade Bašić, Peta kozaračka brigada, Belgrade 1973, p. 215.

55 Associated Press, 'Eyes of Victims in '41 Massacre Haunt German', in: Deseret News, 7 March 1997, URL: https://www.de-

seretnews.com/article/547366/eyes-of-victims-in-41-massacre-haunt-german.html (accessed 2 June 2021). 


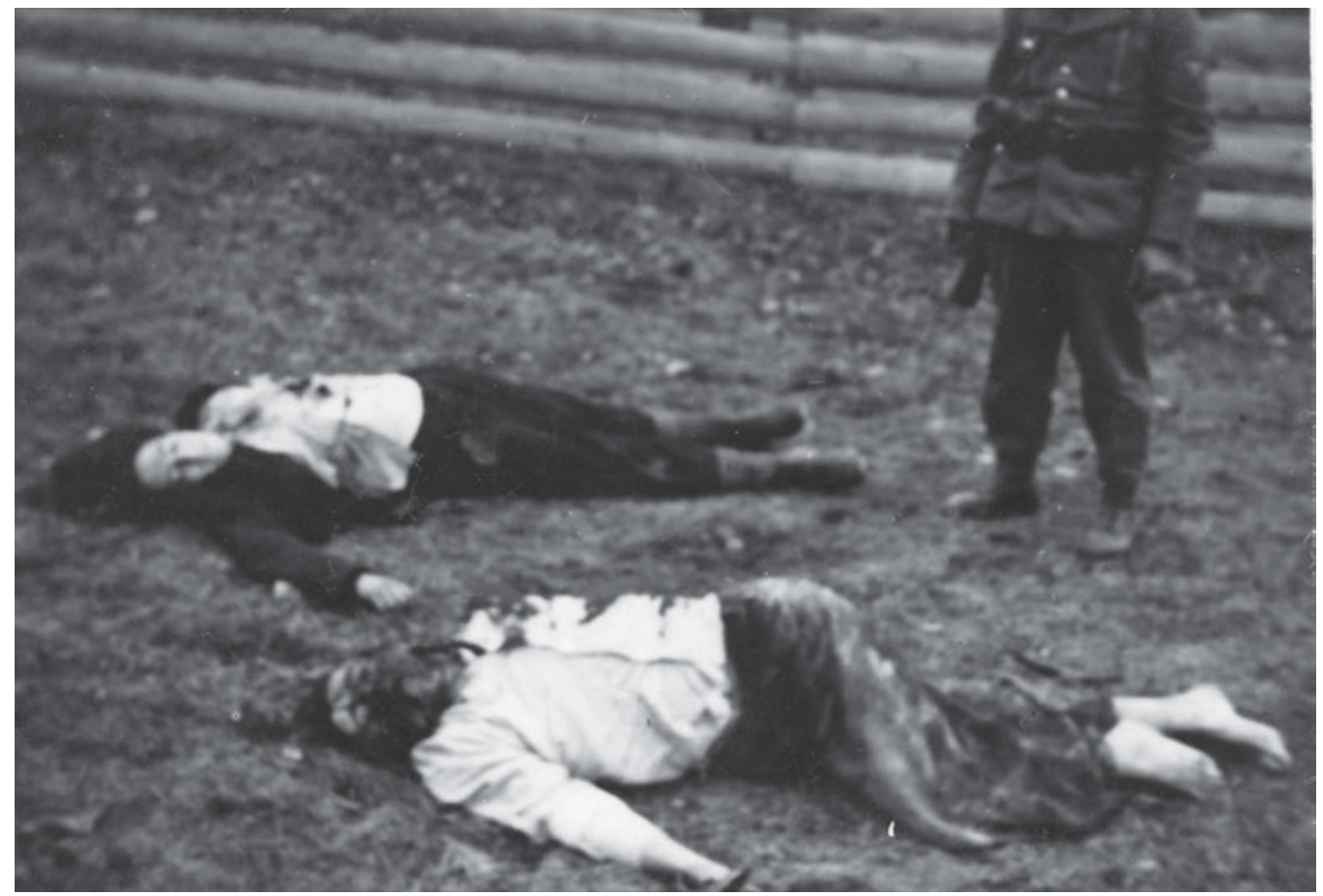

Image from the Nazi album 'Bildarchiv des Kreisses Krainburg', vol. 4. National Museum of Contemporary History of Slovenia.

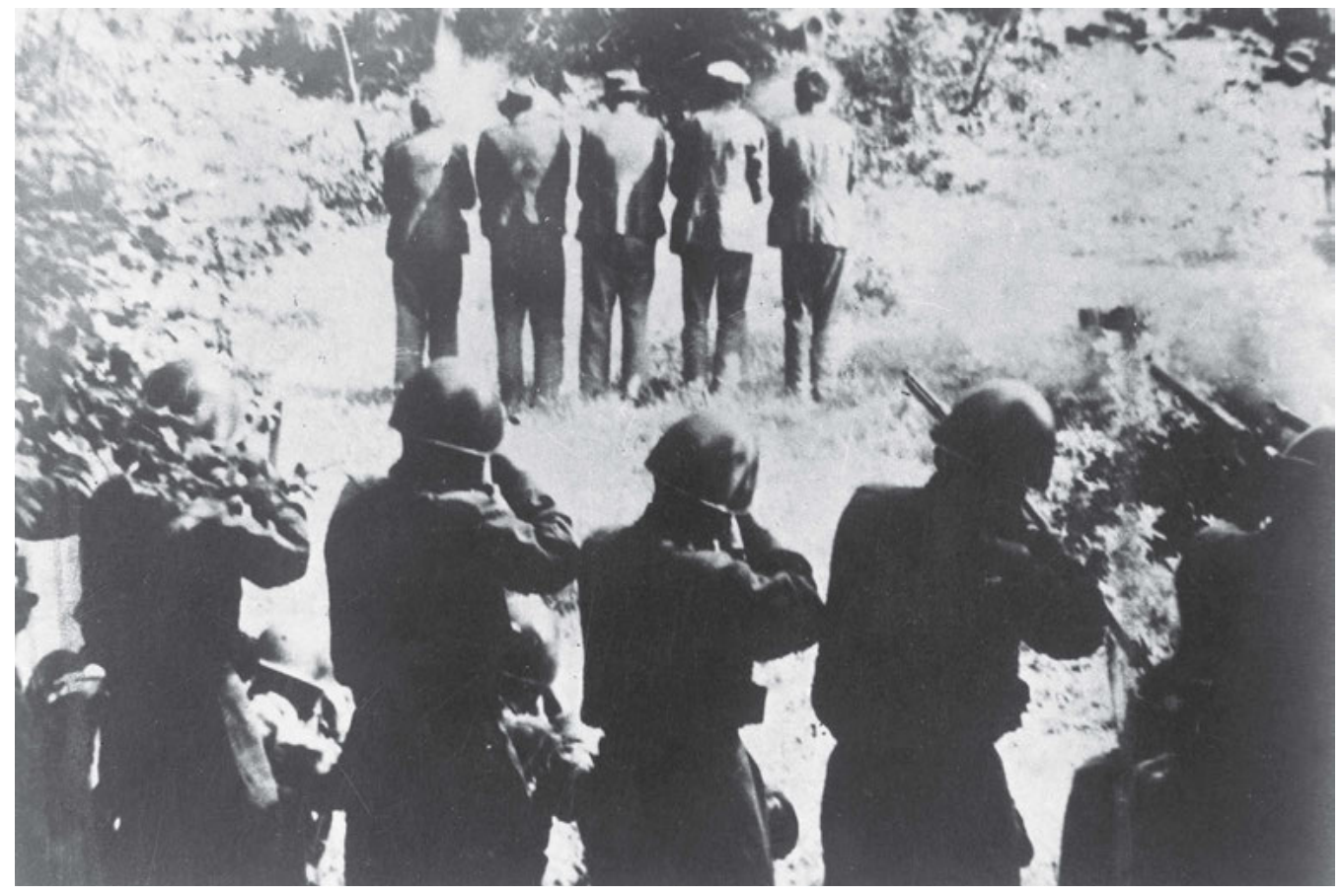

Execution of prisoners Franc Žnidaršič (left), Janez Krajc, France Škerbec, Feliks Žnidaršič, Edvard Škerbec (right). Križna Gora, Loška valley, 31 June 1942. Photographer unknown. National Museum of Contemporary History of Slovenia, 1818. 


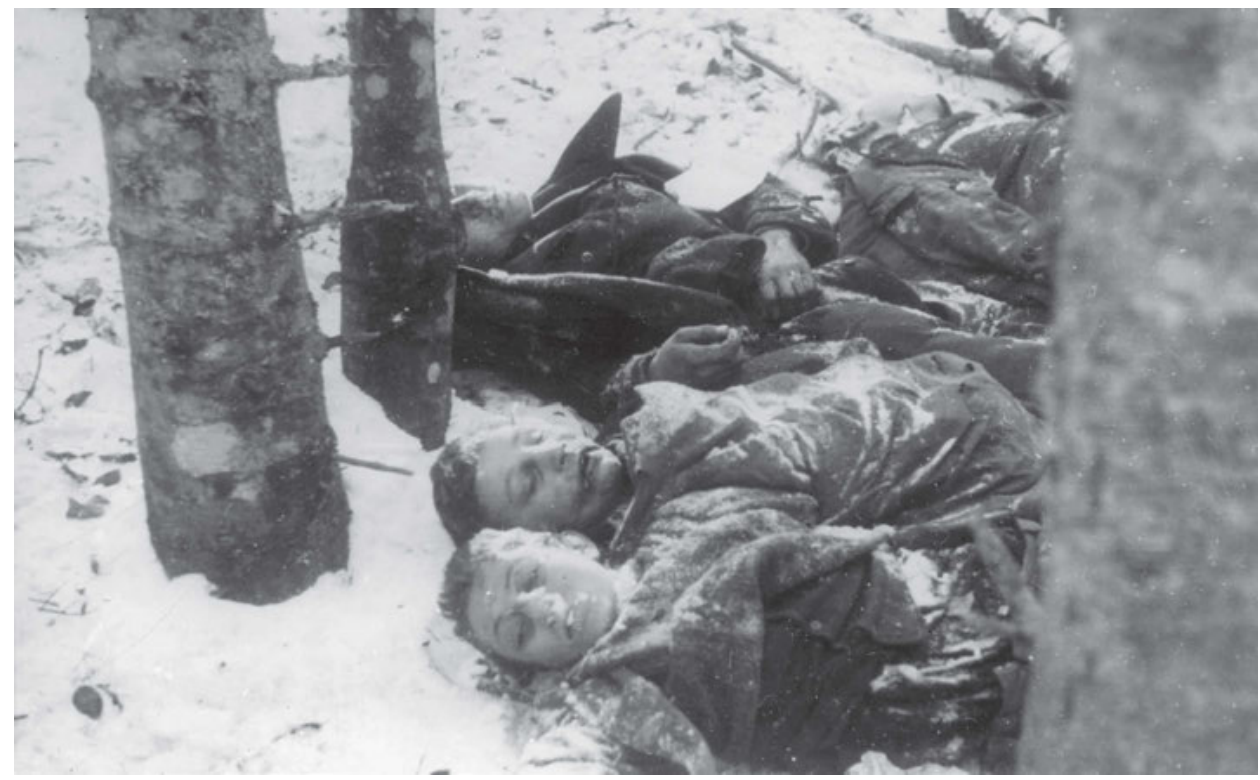

Killed Partisans from the Pohorski Battalion, including child soldiers Vanček Šarh (first from front, age 12) and Pepček Šarh (age 14), sons of the Partisan soldier Alfonz Šarh, who was also killed. Photographer unknown. National Museum of Contemporary History of Slovenia, 4973/9.

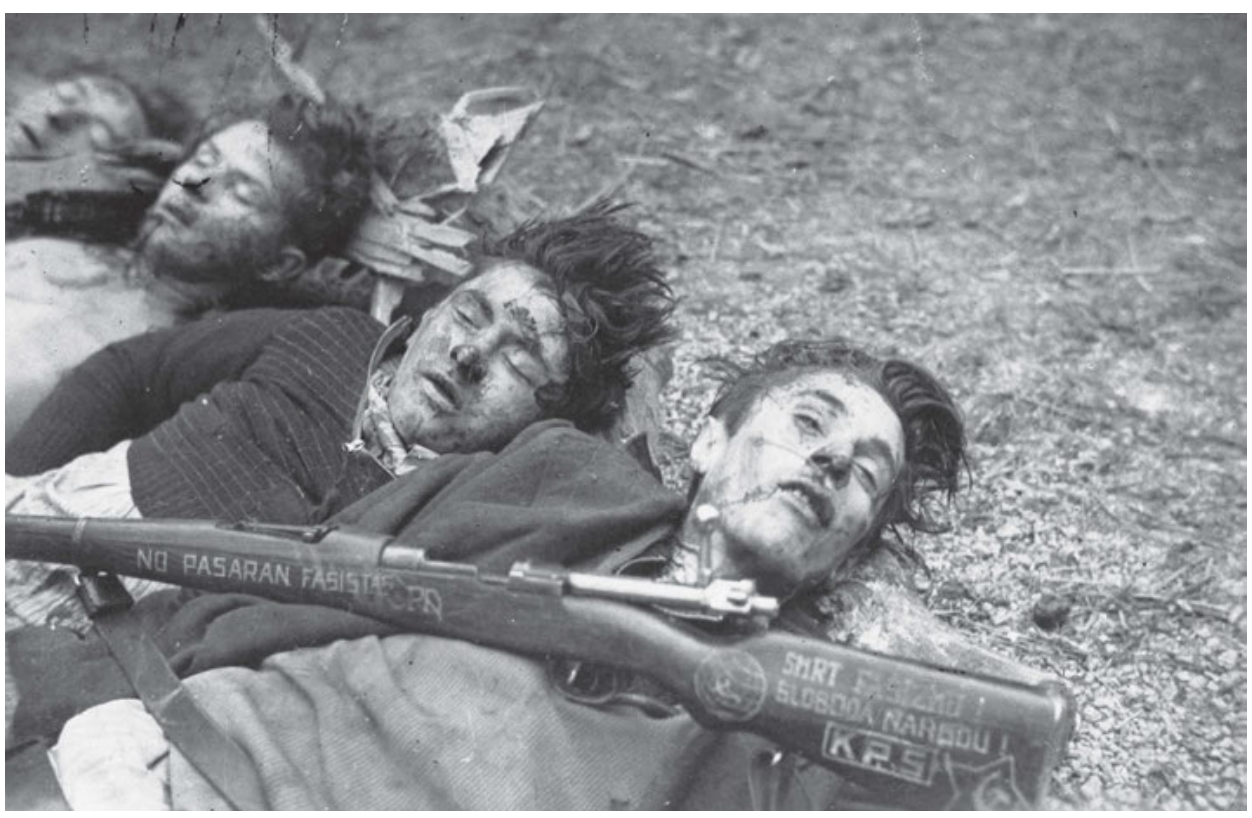

Four fighters from the Brezice Company: Ivan Milavec (left), Marjan Cerjak, Draško Hlebec and Milan Kovačič (right foreground), Podsreda, Slovenia, 28 November 1941. Photographer unknown. National Museum of Contemporary History of Slovenia, pl8864a. 

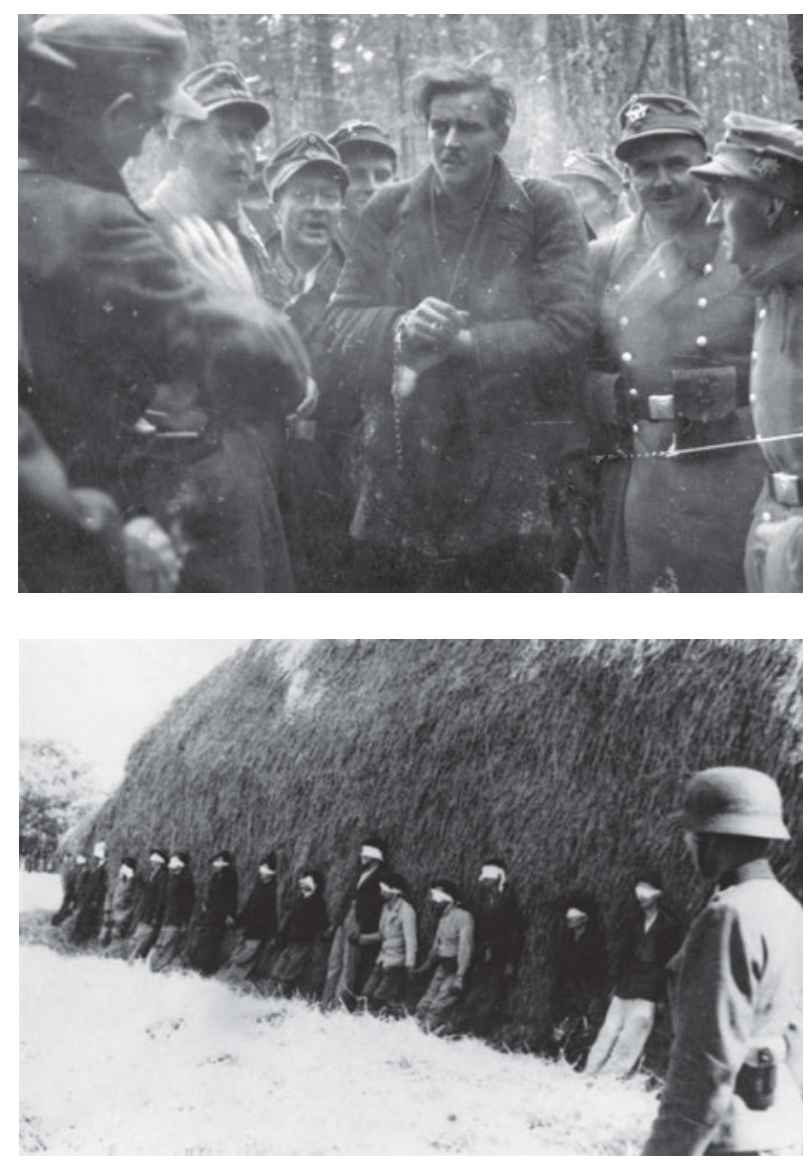

Franc Kunaver, captured fighter from the Pohorski Battalion, with German police, Pohorje, 8 January 1943. Photo: Ordelt Delti. National Museum of Contemporary History of Slovenia, Di1085/1.

Death by firing squad of 17 communists in Smederevska Palanka, Serbia, 20 July 1941. Photographer unknown. Military Museum Belgrade, 1069.

publicly humiliated in front of their comrades' bodies that were strewn around them. Public hangings and executions were methods used to inculcate terror among the population. Retribution killings and exterminations were especially prevalent in South-East Europe, where large swathes of the population fell victim to the race laws. Images of these executions became proof of military orders acted out, ${ }^{56}$ and served to coerce the population further. Throughout history, public hangings have been intended mainly for underprivileged social

The horrific photograph of the hanging of the seventeen-year-old girl Lepa Radic came to be perhaps the most well-known image of suffering, a symbol of the atrocities committed on Yugoslav soil. As a member of the Second Krajina Detachment, Radić, a young hospital nurse, was responsible for evacuating injured soldiers and the civilian population during the Fourth Enemy Offensive in 1943. In the evening of 8 February 1943, her camp was discovered by units of the notorious Seventh SS Volunteer Mountain Division 'Prinz Eugen'. After having shot her final round of ammunition, Lepa was overpowered by being struck in the head with a gunstock and led away to Bosanska Krupa, where, after three days' impri- 
sonment, she was publicly hanged from a false acacia tree not far from the railway station. The art historian Dragoje Lukić, known for researching the deaths of children and civilians from nearby Bosanska Krajina, published an article in Ilustrovana Politika in 1968 on Lepa Radić. The article revealed that the negatives of the photographs of her execution were found on a German soldier who fell on Ilica St. during the liberation of Zagreb. For years, the identity of the girl in the photograph remained unknown and was revealed entirely by chance by a visitor to what was then called the Museum of the Revolution in Mostar. ${ }^{58}$ Thanks to the discovery of these trophy photographs found on the fallen German soldier, we now have further visual evidence of the brutality of the public hanging of this young member of the League of Communist Youth. The expression on her face is defiant, without a trace of fear. But rather than having a galvanising effect, as is the case with the image of Stjepan Filipović on the gallows, these photographs - showing a girl surrounded by a group of men who would, moments later, eagerly remove her shoes and jacket as 'war spoils' -

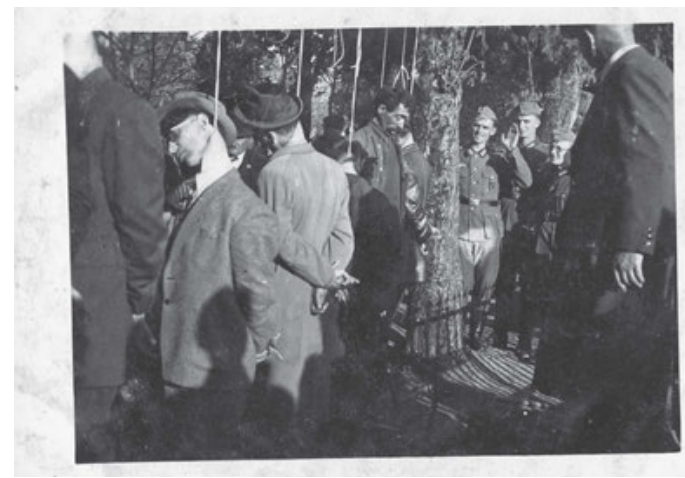

The hanging of civilians, Pančevo, 22 June 1941. Photograph found on a dead German soldier. Photographer unknown. Yad Vashem, 8053985.

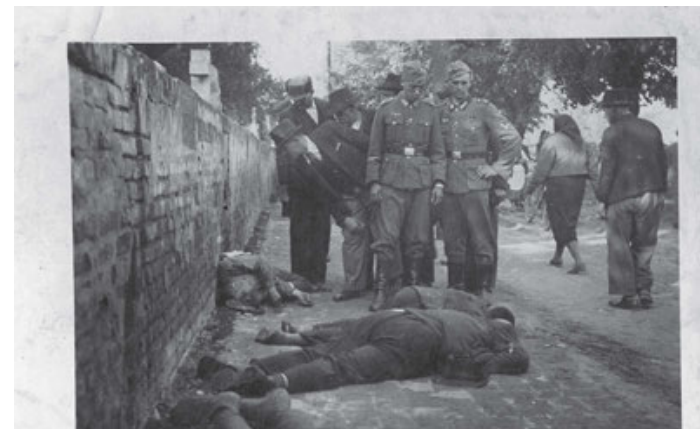

Executed civilians, Pančevo, 22 June 1941. Photograph found on a dead German soldier. Photographer unknown. Yad Vashem, 8053996.

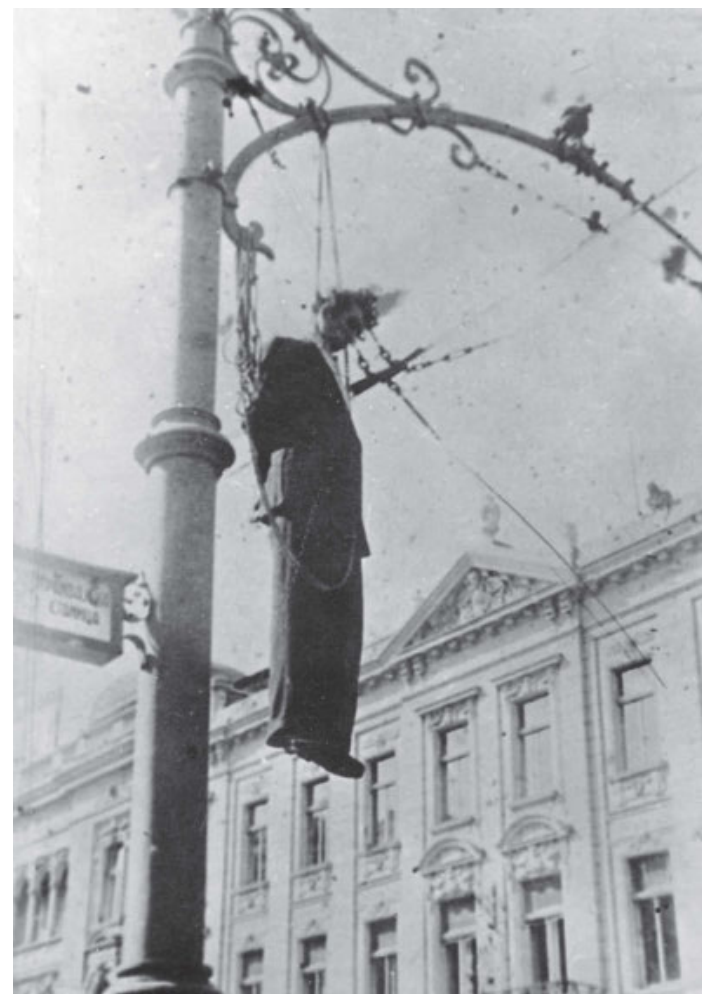

Jovan Janković, a tailor from Belgrade, hanged by the German occupiers on Terazije, a central square in Belgrade, 17 August 1941. Photographer unknown. Military Museum Belgrade, 1022.

57 Ibid., p. 190.

58 Dragoje Lukić, 'Lepa Radić 1943. nije imala ni 18 godina: Kako su otkriveni potresni snimci vešanja mlade partizanke', in: /lustrovana Politika, 1968, quoted from: Yugopapir, URL: http://www.yugopapir.com/2017/10/lepa-radic-43-nije-imala-ni-18-godina.html (accessed 2 June 2021). 

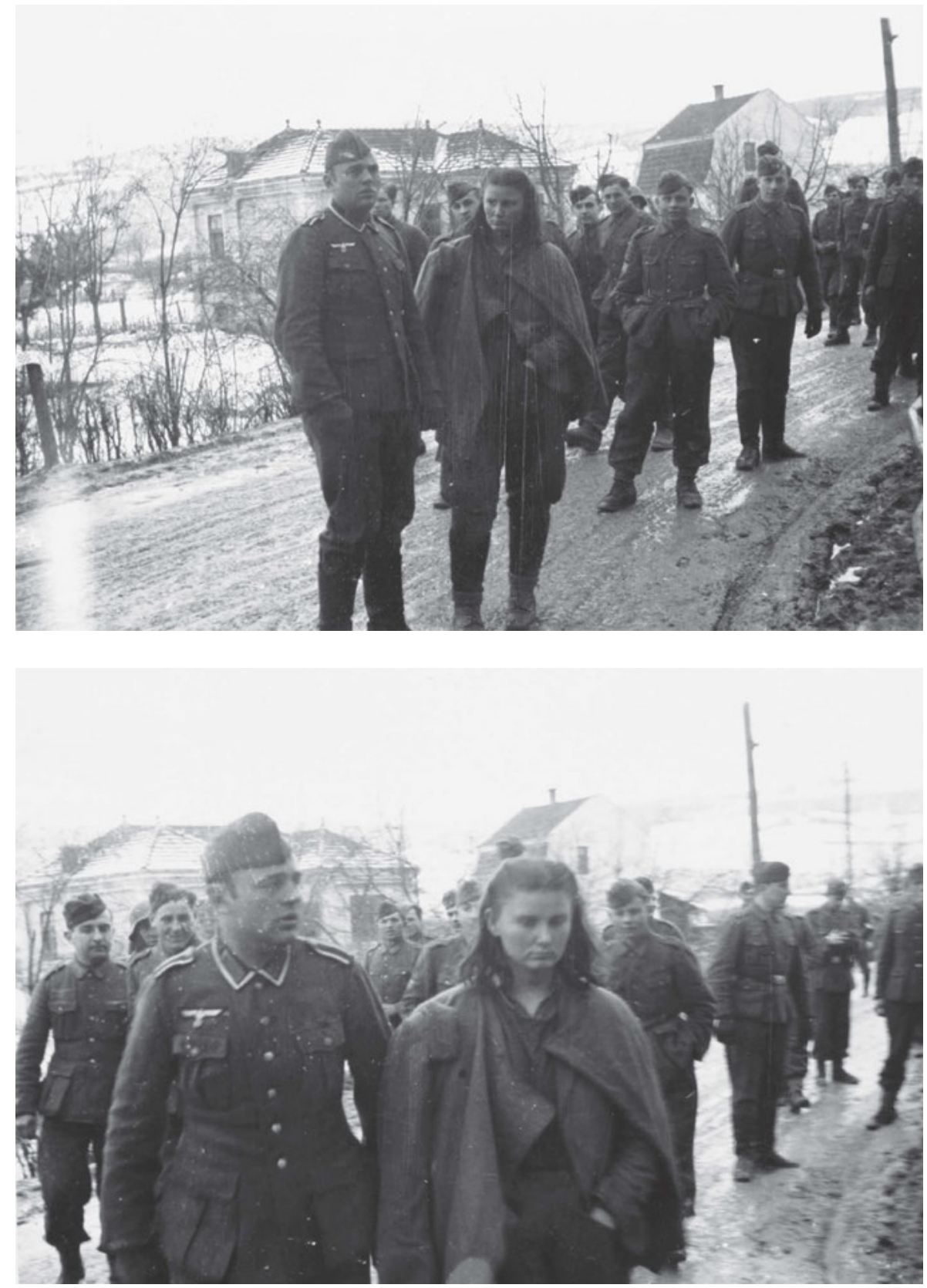

Lepa Radić, later declared a People's Hero, immediately before her hanging, at age 17, in Bosanska Krupa, 8 February 1943. Photographer unknown. Photograph donated by Dragoje Lukić.

leave the viewer with an overriding sense of helplessness and convey the 'banality of evil'. Although the Axis powers primarily used photography to terrify and coerce the civilian population under occupation, once they fell into Partisan hands, these same photographs had the exact opposite effect. Photographic evidence of atrocities underscored a heroic narrative of human sacrifice so that 'despite high risks and the threat of violence, they served as a sign of the groundswell of resistance among the people and their determined resolution to join and support a resistance movement led by the Communist Party of 
Yugoslavia, which laid the foundations for the future political and social order after the war'.59 Instead of being intimidating, photographs of war crimes only hardened the resolve of soldiers and fighters to take an even stronger stand against the enemy. It is therefore unsurprising that by 20 October 1942, the head of the temporary administrative section of the Supreme Command, Moša Pijade, had already asked that Partisans gather all proof of enemy war crimes. He stressed that such photographs could even be acquired from within occupied Zagreb. ${ }^{60}$ Some of the first examples of photographs taken by the occupying forces but published by Partisans appeared in the paper Borba, issue 15, 29 November 1944, under the heading 'We avenge the blood and suffering of our brothers from the Slovenian Littoral'. ${ }^{61}$

It is important to mention here, once again, that Partisan photography emerged within the Partisan movement, whose right to exist was denied by the German occupiers and quisling authorities. ${ }^{62}$ The only route out of this situation was armed resistance to preserve and maintain the civilizational and emancipatory achievements of modern humankind. ${ }^{63}$ The Partisans did not revere and fetishise death in their photographs, a key point of difference
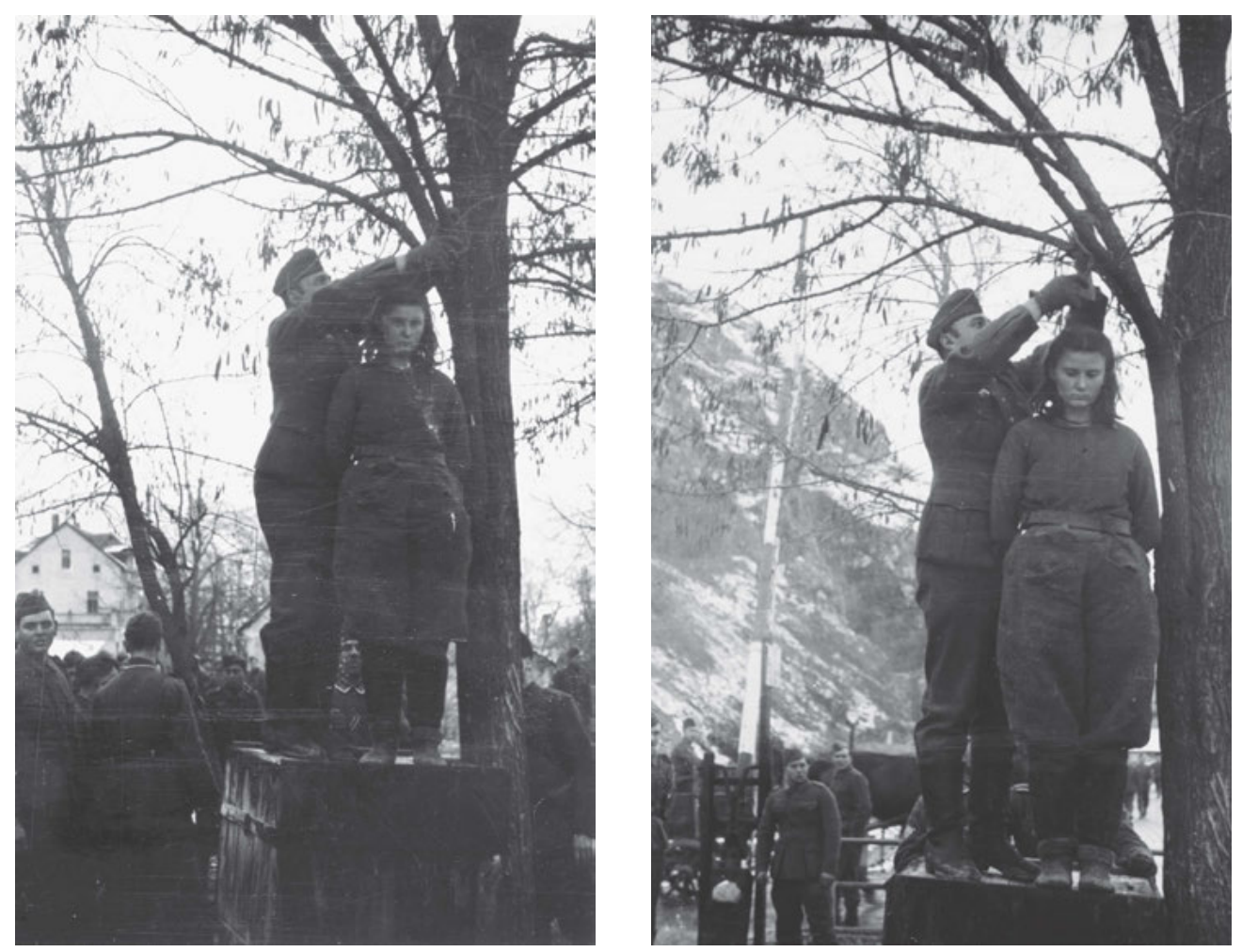

Lepa Radić, later declared a People's Hero, immediately before her hanging, at age 17, in Bosanska Krupa, 8 February 1943. Photographer unknown. Photograph donated by Dragoje Lukić.

59 Horvatinčić, p. 191.

60 Zbornik dokumenata i podataka o narodno-oslobodilačkom ratu jugoslovenskih naroda, vol. II/6: Dokumenta vrhovnog štaba Narodnooslobodilačke vojske Jugoslavije 1942, Belgrade 1957.

61 Sandra Vitaljić, Rat slikama. Suvremena ratna fotografija, Zagreb/Mostar 2013, p. 92.

62 Krunoslav Stojaković, 'Revolucionarno nasilje u narodnooslobodilačkom ratu', in: Milan Radanović, Kazna i zločin: Snage kolaboracije u Srbiji, Belgrade 2014 (Rosa Luxemburg Stiftung Southeast Europe), p. 21.

63 Ibid., p. 24. 


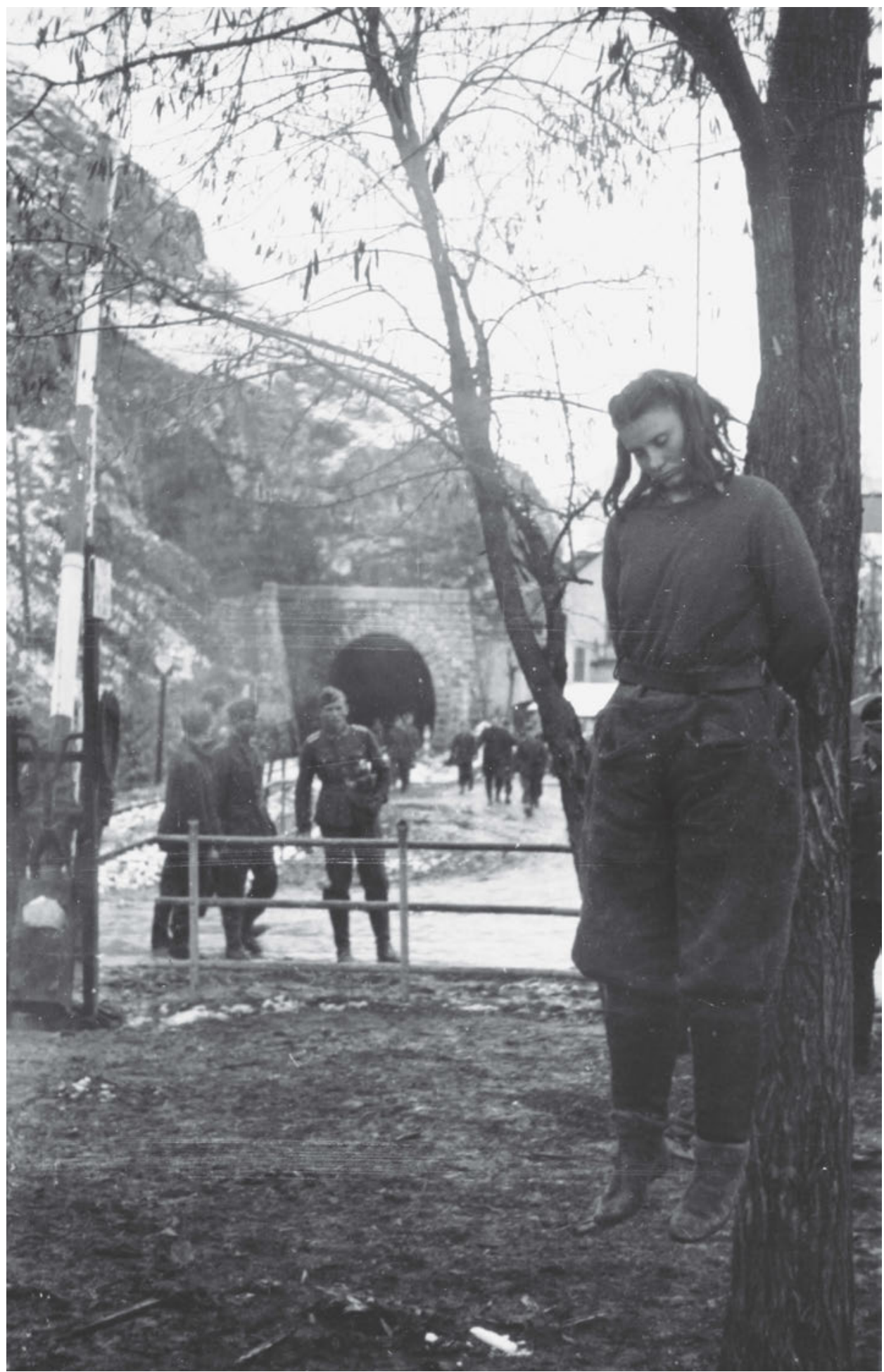

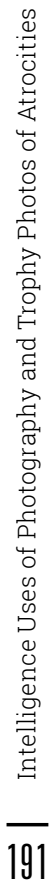

Lepa Radić was executed at age 17, in Bosanska Krupa, 8 February 1943. Photographer unknown. Photographs donated by Dragoje Lukić. 
with Nazi and fascist ideology and culture. The Nazi reverence of death is evidenced in their use of such imagery as skulls (for example the skull-and-crossbones insignia of the SS), bones, knives, etcetera, and also through various occult rituals that gained traction in certain Nazi circles. Ultimately, Hitler, whose favourite opera coincidentally was Wagner's Götterdämmerung, saw death as valiant and a higher form. With a death cult prevailing in Nazi Germany, not just in political discourse but also in art, it was therefore entirely logical that the Germans used photographs of their own dead for propaganda purposes. The Partisans, by contrast, did not photograph their dead, as for them death in and of itself was not a symbol of pride, but rather defeat, and this was an important difference in their everyday practice.

Photographs of Partisan executions of captured enemy soldiers were forbidden in a series of orders from 1941 onwards. One of the rare examples of such photographs was shot by Croatian photographer Hugo Fischer Ribarić during the struggle for the liberation of Rijeka. It was shot above Vežica, not far from the astronomy centre there today. As an established photographer, he certainly knew that he was breaking all the war regulations, but irrespective of this, he decided to photograph the execution of German soldiers and publish the photographs. He most likely did so to express his objections against his superiors' decision to execute prisoners of war. 


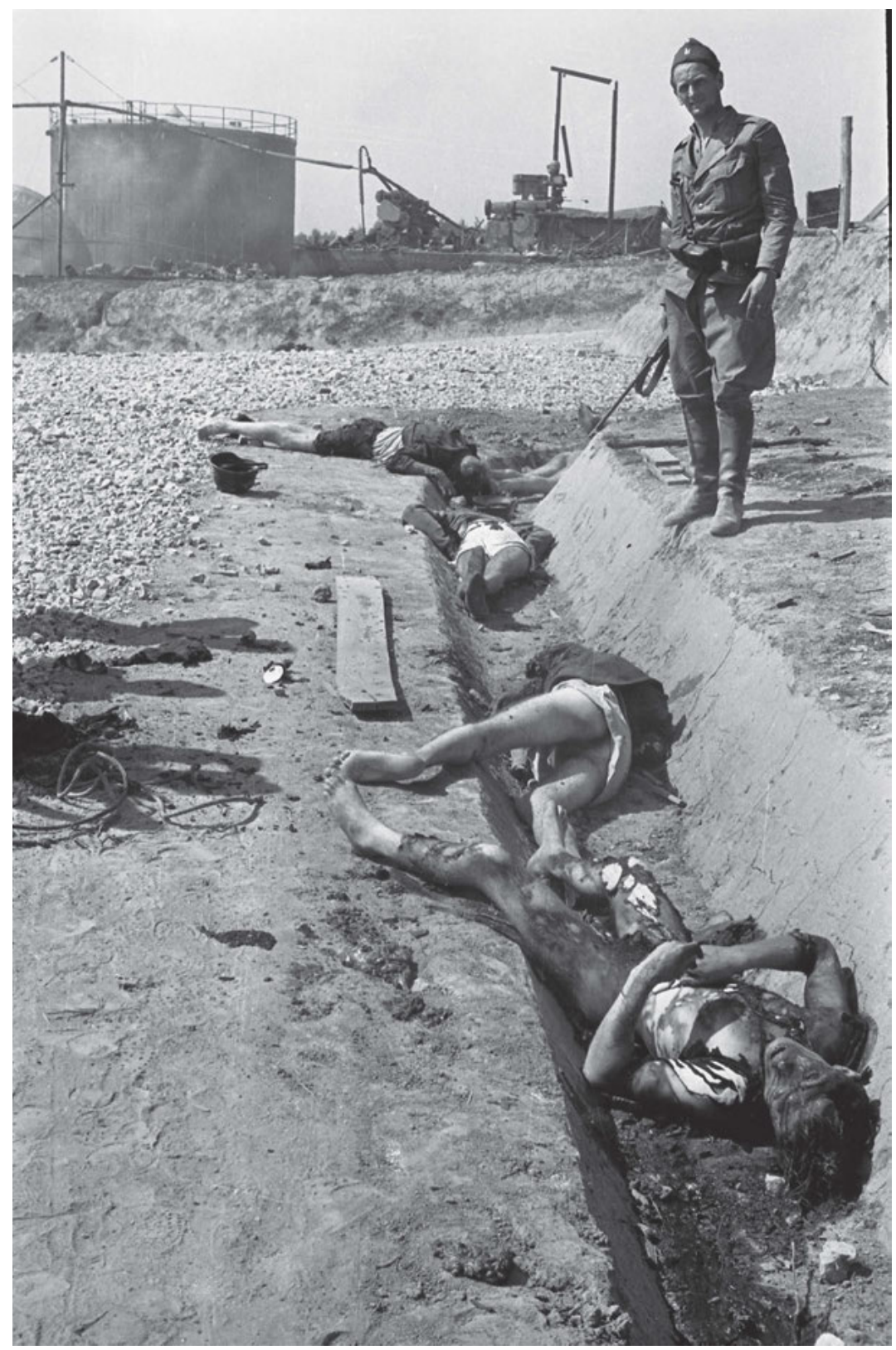

A Ustashe soldier stands above his victims after the Partisan ambush on Gojlo, 6 September 1942. Photo: Dragutin Rajterić (Croatian Film Service). Croatian History Museum, HPMMRNH-N-6751. 


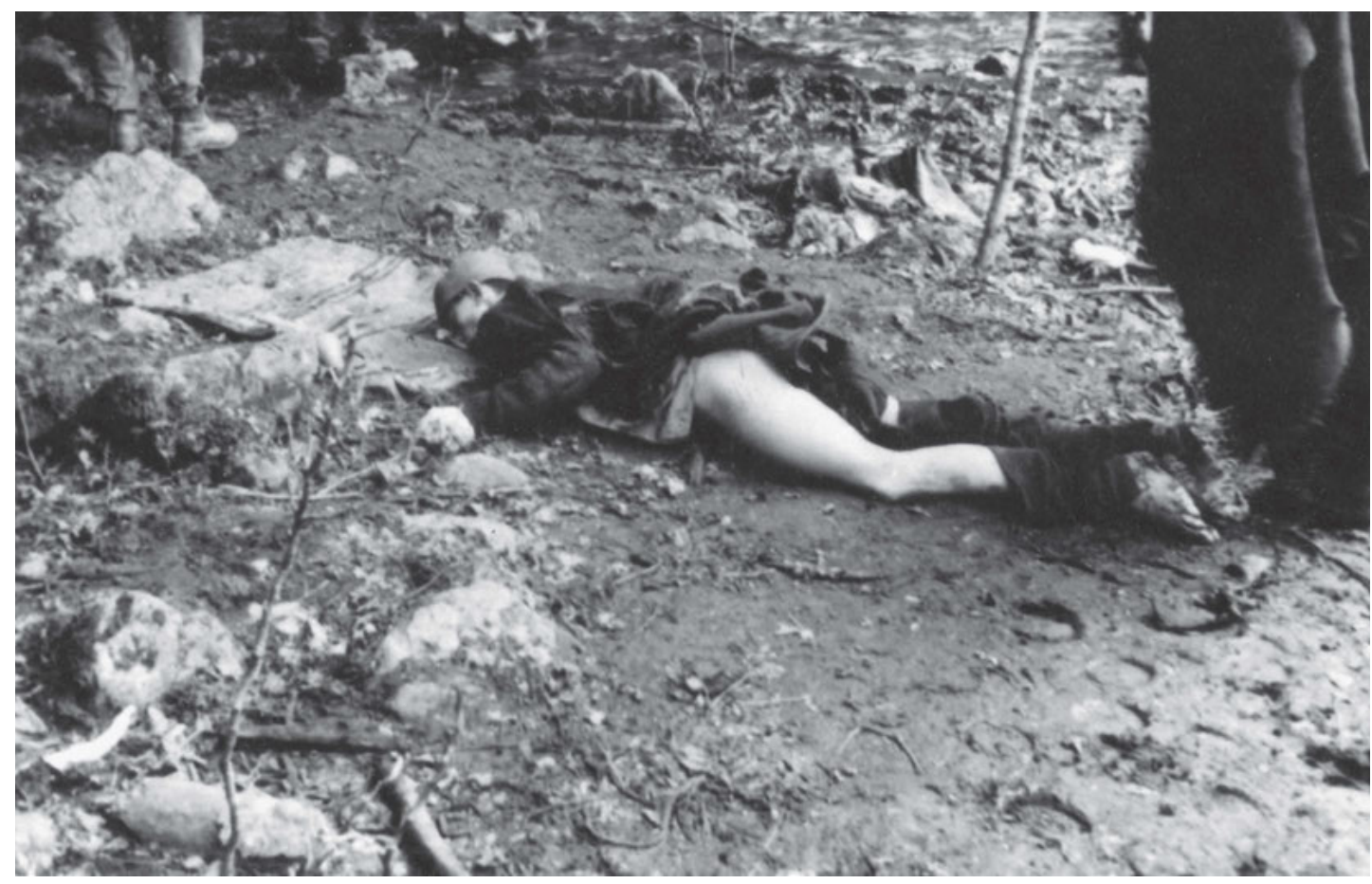

Unknown victim, Bosnia and Herzegovina, 1943. Photo: Mladen Iveković. Croatian History Museum, HPMMRNH-A-6337 165. 